\title{
Infralittoral ostracoda and benthic foraminifera of the Gulf of Pozzuoli (Tyrrhenian Sea, Italy)
}

\author{
Giuseppe Aiello $(\mathbb{D} \cdot$ Diana Barra $\cdot$ Roberta Parisi $\cdot$ Michele Arienzo • \\ Carlo Donadio $\cdot$ Luciano Ferrara $\cdot$ Maria Toscanesi $\cdot$ Marco Trifuoggi
}

Received: 17 January 2021 / Accepted: 17 May 2021 / Published online: 15 June 2021

(C) The Author(s) 2021

\begin{abstract}
The shallow water benthic foraminiferal and ostracod assemblages of the Gulf of Pozzuoli, located in the central Tyrrhenian Sea, were studied to investigate the relationship between calcareous meiofaunas and contaminant concentrations in bottom sediments exposed to prolonged industrial pollution. Both benthic foraminifers and ostracods displayed high-diversity and low-dominance, unusual features in highly contaminated environments. High-diversity values were possibly linked to the oligotrophic, welloxygenated, and $\mathrm{CaCO}_{3}$-supersaturated coastal Mediterranean waters. The comparison with historical data suggested that assemblage composition changed in the last decades, with an increase in the relative abundance of benthic foraminiferal (Quinqueloculina
\end{abstract}

Handling Editor: Télesphore Sime-Ngando.

G. Aiello $(\bowtie) \cdot$ D. Barra $\cdot$ R. Parisi .

M. Arienzo - C. Donadio

Dipartimento di Scienze della Terra, dell'Ambiente e

delle Risorse, Università di Napoli Federico II, via Cintia

21, 80126 Naples, Italy

e-mail: giuseppe.aiello@unina.it; aie641lo@hotmail.com

D. Barra

Istituto Nazionale di Geofisica e Vulcanologia, Sezione di Napoli Osservatorio Vesuviano, Via Diocleziano 328, 80124 Naples, Italy

L. Ferrara $\cdot$ M. Toscanesi $\cdot$ M. Trifuoggi

Dipartimento di Scienze Chimiche, Università degli Studi

di Napoli Federico II, via Cintia 21, 80126 Naples, Italy seminulum, Bulimina elongata) and ostracod (Xestoleberis, Loxoconcha, Semicytherura rarecostata) taxa. They probably represent organisms tolerant to the environmental variations in the last decades. The relationships between granulometry and diversity indices, high correlation values between Quinqueloculina lata and heavy metal pollution, and the preference of the ostracod genera Urocythereis and Paracytheridea for very shallow marine waters were highlighted.

Keywords Meiobenthos - Granulometry · Mediterranean Sea $\cdot$ Industrial pollution $\cdot$ Highdiversity assemblages

\section{Introduction}

Benthic foraminifers (Rhizaria) and ostracods (Crustacea) are meiofaunal groups generally provided with calcareous tests and valves, commonly preserved in sea bottom sediments. The composition of their assemblages reflects environmental conditions due to both natural and human causes. Anthropogenic activities produce various effects on shallow marine waters, including organic pollution, changes in sedimentation rates, increase in hydrocarbon and heavy metal concentrations, and eutrophication-induced hypoxia (Gooday et al., 2009; Yasuhara et al., 2012; Wilkinson et al., 2014) that, in turn, lead to an increase in the 
relative abundance of stress-tolerant foraminiferal species (Hayward et al., 2004; Alve et al., 2009; Frontalini and Coccioni, 2011; Ruiz et al., 2012) and frequently to ostracod diversity decrease (Alve, 1991; Mazzola et al., 1999; Cronin \& Vann, 2003; Irizuki et al., 2018). The studies combining the analyses of benthic foraminifers and ostracods in areas where human-induced ecological variations occurred showed the high potential of calcareous meiofaunal assemblages as water quality indicators (Samir, 2000; Triantaphyllou et al., 2003, 2005; Vilela et al., 2003; Bergin et al., 2006; Pascual et al., 2008, Salvi et al., 2015).

In the present study, benthic foraminiferal and ostracod assemblages were studied from eleven samples collected in the infralittoral zone of the Gulf of Pozzuoli, a bay located in the Campania region (Southern Italy) with a narrow continental shelf, a shelf break at about $40 \mathrm{~m}$ bsl, a maximum depth of $110 \mathrm{~m}$, and an average depth of ca. $60 \mathrm{~m}$ (Fig. 1; Somma et al., 2016). The gulf is mainly exposed to winds and sea waves approaching from the southeast- southwest sector, with a maximum geographic fetch of $665 \mathrm{~km}$ for the $205^{\circ}$ direction, 0.9-2.2 $\mathrm{m}$ average wave height, and a maximum wave height of $4.7 \mathrm{~m}$ in winter (De Pippo et al., 2008). The water circulation models (De Maio et al., 1985; Menna et al., 2008; de Ruggiero, 2016) of the gulf generally indicate two main flow patterns: (i) when the open sea currents flow toward the southeast, the inner waters of the bay are cut off in a slow cyclonic gyre; then, the coastal waters slow motion could favor turbidity and a high pollutant concentration; (ii) when the open sea currents flow toward the northwest, some branches enter into the bay; then, a fair renewal of sea waters occurs. Tides are negligible, with a syzygial tide amplitude of $0.35 \mathrm{~m}$ (Tammaro et al., 2021); therefore, the gulf is a wavedominated environment. Salinity, turbidity, and phytoplankton distribution are related to seasonal variation in the sea surface and column temperature, autumn-winter freshwater supply by rainfalls and land runoff, marine currents cell circulation: $37.1-38.6 \%$ salinity, $27-30^{\circ} \mathrm{C}$ sea surface temperature, and high phytoplankton biomass (Chl a

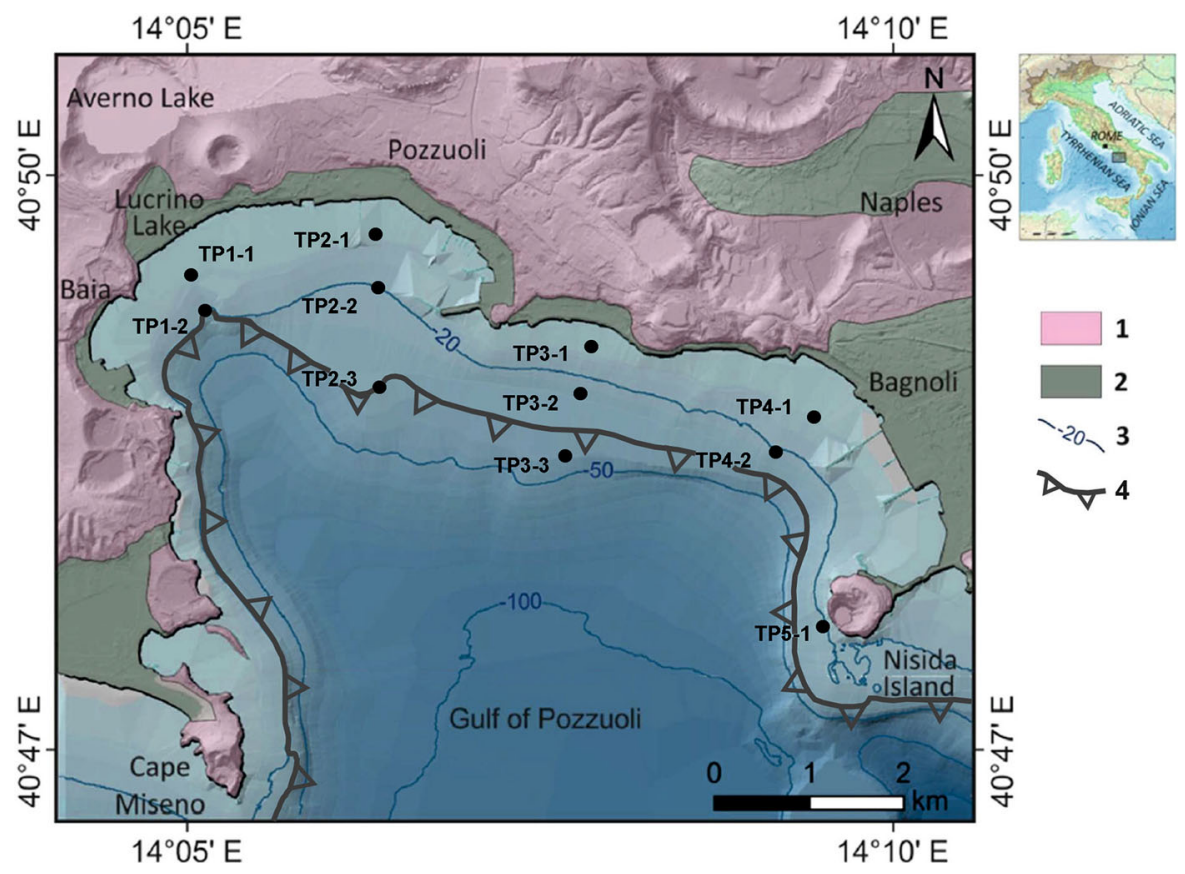

Fig. 1 Location of the sampling stations (black solid circle) in the Gulf of Pozzuoli. Legend: 1, pyroclastics of the Phlegrean Fields (Late Pleistocene-Holocene); 2, deposits of transitional environments (Quaternary); 3, isobath(-m); 4, edge of the continental shelf break, from a depth of about 25 down to $40 \mathrm{~m}$. Depth is in meters b.s.l. (after Somma et al., 2016 and the morphobathymetric and sedimentological surveys carried out for this research). The geographic coordinate system is WGS84 
concentration $>2 \mu \mathrm{g} / \mathrm{L}$ ) were registered during the spring-summer season (Bolinesi et al., 2020). The bay was exposed to prolonged anthropogenic disturbance, due to urban and industrial wastes, at least since 1885 , when an armaments factory was built by the British company Armstrong Mitchell \& Co. The eastern part of the gulf was under the influence of the Bagnoli steel plant from 1910 to 1990 , to which the high levels of polycyclic aromatic hydrocarbons (Arienzo et al., 2017; Ferrara et al., 2020), trace metals (Trifuoggi et al., 2017), and rare earth elements (Trifuoggi et al., 2018) in the sediment seem to be linked. Recently, some ecological and paleoecological investigations were performed on Recent (Balassone et al., 2016; Mangoni et al., 2016; Arienzo et al., 2020) and late Quaternary (i.e., from $\sim 150 \mathrm{ka}$ to historical times; Aiello et al., 2012; 2018; 2020; 2021; Amato et al., 2019; Petrosino et al., 2021) sediments of the Campania region coastal areas focused on benthic foraminiferal and ostracod assemblages. The present study aims to define the characteristics of the calcareous meiofaunal assemblages in the infralittoral zone (Peres \& Picard, 1964; Peres, 1982) of an area showing high geoaccumulation values and to test a possible decrease in benthic faunal abundance and diversity in polluted bottom sediments. Our data, compared with the above-mentioned studies and previous investigations on Campanian infralittoral benthic foraminifers (Moncharmont Zei, 1964; Sgarrella \& Barra, 1985; Sgarrella et al., 1985; Sgarrella \& Moncharmont, 1993) and ostracods (Müller, 1894;
Puri et al., 1964, 1969), may contribute to a more complete understanding of the relationship between meiofaunal assemblages and environmental parameters.

\section{Material and methods}

Eleven samples of very fine to coarse sands, and very fine gravels, were collected by a Van Veen grab above the shelf break of the Gulf of Pozzuoli ( $\sim 40 \mathrm{~m} \mathrm{bsl}$ ), in a water depth range between $7.5 \mathrm{~m}$ and $38 \mathrm{~m}$, within the infralittoral zone. The grab collected superficial sediments, including the first ca. $5 \mathrm{~cm}$ of the seabed, related to texture and consistency of silt or sand deposits. Sharp \& Nardi (1987) calculated, in this area, a sedimentation rate of about $4 \mathrm{~mm} /$ year and consequently the sampled sediments deposited, at most, in the last 15 years. The surface of the sampler is about 150 square $\mathrm{cm}(10 \times 15 \mathrm{~cm})$, while the volume of the sampled sea bottom surface sediment generally is about 750-1000 cubic cm. Samples were taken along one campaign in the spring of 2017 along transects and aboard a motor vessel. Bathymetry, grain size, number, and location of samples are reported in Fig. 1 and Table 1. For meiofaunal analyses, all the samples were oven-dried, and $100 \mathrm{~g}$ of dry sediment was taken. They were washed through 230-mesh $(63 \mu \mathrm{m})$ and 120 -mesh $(125 \mu \mathrm{m})$ sieves, and the residues were oven-dried and examined with a reflected light microscope. A microsplitter was used

Table 1 Coordinates of sampling stations, grain size, and water depth

\begin{tabular}{|c|c|c|c|c|c|c|c|c|}
\hline Sampling stations & Latitude (N) & Longitude (E) & Depth (m) & Gravel \% & Sand $\%$ & Silt $\%$ & Clay \% & Class \\
\hline $\mathrm{TP} 1-1$ & $40^{\circ} 49^{\prime} 27.55^{\prime}$ & $14^{\circ} 05^{\prime} 02.94^{\prime \prime}$ & 8.0 & 4.68 & 94.9 & 0.33 & 0.05 & Fine sand \\
\hline TP1-2 & $40^{\circ} 49^{\prime} 16.89^{\prime \prime}$ & $14^{\circ} 05^{\prime} 08.74^{\prime \prime}$ & 24.8 & 1.59 & 97.3 & 0.96 & 0.16 & Fine sand \\
\hline $\mathrm{TP} 2-1$ & $40^{\circ} 49^{\prime} 41.34^{\prime \prime}$ & $14^{\circ} 06^{\prime} 19.46^{\prime \prime}$ & 8.0 & 0.69 & 99.3 & - & - & Coarse sand \\
\hline $\mathrm{TP} 2-2$ & $40^{\circ} 49^{\prime} 23.95^{\prime \prime}$ & $14^{\circ} 06^{\prime} 21.93 "$ & 25.8 & 1.50 & 97.0 & 1.40 & 0.10 & Very fine sand \\
\hline $\mathrm{TP} 2-3$ & $40^{\circ} 48^{\prime} 42.91^{\prime \prime}$ & $14^{\circ} 06^{\prime} 29.06^{\prime \prime}$ & 34.0 & 6.72 & 91.8 & 1.32 & 0.15 & Fine sand \\
\hline TP3-1 & $40^{\circ} 49^{\prime} 05.98^{\prime \prime}$ & $14^{\circ} 07^{\prime} 50.41^{\prime \prime}$ & 7.5 & 0.67 & 99.3 & - & - & Medium sand \\
\hline TP3-2 & $40^{\circ} 48^{\prime} 53.02^{\prime \prime}$ & $14^{\circ} 07^{\prime} 46.26^{\prime \prime}$ & 23.8 & 5.10 & 94.9 & - & - & Fine sand \\
\hline TP3-3 & $40^{\circ} 48^{\prime} 33.38^{\prime \prime}$ & $14^{\circ} 07^{\prime} 38.47^{\prime \prime}$ & 38.0 & 2.89 & 96.1 & 0.88 & 0.12 & Fine sand \\
\hline ТP4-1 & $40^{\circ} 48^{\prime} 46.43^{\prime \prime}$ & $14^{\circ} 09^{\prime} 30.87^{\prime \prime}$ & 7.7 & 0.06 & 99.9 & - & - & Fine sand \\
\hline $\mathrm{TP} 4-2$ & $40^{\circ} 48^{\prime} 32.74^{\prime \prime}$ & $14^{\circ} 09^{\prime} 17.63^{\prime \prime}$ & 21.5 & 0.57 & 98.9 & 0.47 & 0.07 & Fine sand \\
\hline TP5-1 & $40^{\circ} 47^{\prime} 33.96^{\prime \prime}$ & $14^{\circ} 09^{\prime} 28.91^{\prime \prime}$ & 22.7 & 49.1 & 50.8 & - & - & Very fine gravel \\
\hline
\end{tabular}


to obtain subsamples when necessary. About 300 benthic foraminiferal tests and 300 ostracod valves were picked from the coarsest fraction $(>125 \mu \mathrm{m})$, classified, and counted. Abundance and diversity indices were calculated using the number of foraminiferal specimens, the ostracod Minimum Number of Individuals (MNI), and the Total Number of Valves (TNV). MNI is the greater number between right and left adult valves plus the number of adult carapace; when only juvenile shells (j) were recorded, the MNI equals one. TNV includes all the adult and young instar valves. Assemblage composition as well as diversity indices was considered for environmental discussion. The following indices were calculated: $\mathrm{S}$ (taxa richness), I (individuals per $100 \mathrm{~g}$ of sediment), D (dominance), H' (Shannon's diversity index, using natural logarithm), and $\mathbf{J}$ (equitability). The species were identified according to classic and modern literature both for benthic foraminifers and ostracods (Aiello \& Barra, 2010; Aiello et al., 2018, and references therein). The studied specimens are housed in the Aiello Barra Micropaleontological Collection (A.B.M.C.), Dipartimento di Scienze della Terra, dell'Ambiente e delle Risorse, Università degli Studi di Napoli Federico II. Statistical analyses were performed using abundance values of foraminiferal ( $\mathrm{I}=$ number of individuals per $100 \mathrm{~g}$ ) and ostracod (both $\mathrm{MNI}=$ minimum number of individuals per $100 \mathrm{~g}$, and TNV = total number of valves per $100 \mathrm{~g}$ ) assemblages. Q-mode cluster analysis (paired group as an algorithm, Rho as similarity measure) was performed to determine groups of samples with similar meiofaunal composition, using abundance values of all foraminiferal and ostracod (both MNI and TNV) species. Pearson's correlation coefficient was used to test for correlation between assemblage features, depth, major and trace elements, and polycyclic aromatic hydrocarbons of eight fine-grained samples; benthic foraminiferal and ostracod species with relative abundance greater than 5\% in at least two samples were considered. The abiotic variables were subject to $\mathrm{z}$-standardization. Analyses were carried out on the same set of samples used by Arienzo et al. (2017), Trifuoggi et al. (2017, 2018), and Ferrara et al. (2020) in their investigations on the distribution of polycyclic aromatic hydrocarbons (PAHs), trace metals (HMs), and rare earth elements (REEs). All the analytical determinations were performed in triplicate for each sample taken at each site. The quality of the analytical results is assured by participation in ring tests for the determination of HMs, PAHs, and REEs from sediments and similar matrices. Mean recoveries ranged from a minimum of $85 \%$ to a maximum of $97 \%$. Grain size analyses were performed following the standard methodology of Folk and Ward (1957). Full methodological details on sampling techniques, geochemical and grain size analyses were reported in Arienzo et al. (2017), Trifuoggi et al. (2017, 2018), and Ferrara et al. (2020).

Computation of diversity indices and statistical analysis were performed with STATISTICA 5 (StatSoft Inc., Tulsa, OK, USA).

Table 2 Benthic foraminiferal absolute abundance ( $\mathrm{I}=$ individuals per $100 \mathrm{~g}$ of sediment)

\begin{tabular}{|c|c|c|c|c|c|c|c|c|}
\hline Sampling stations & Latitude $(\mathrm{N})$ & Longitude (E) & Depth (m) & Gravel \% & Sand $\%$ & Silt \% & Clay $\%$ & Class \\
\hline TP1-1 & $40^{\circ} 49^{\prime} 27.55^{\prime \prime}$ & $14^{\circ} 05^{\prime} 02.94^{\prime \prime}$ & 8.0 & 4.68 & 94.9 & 0.33 & 0.05 & Fine sand \\
\hline $\mathrm{TP} 1-2$ & $40^{\circ} 49^{\prime} 16.89^{\prime \prime}$ & $14^{\circ} 05^{\prime} 08.74^{\prime \prime}$ & 24.8 & 1.59 & 97.3 & 0.96 & 0.16 & Fine sand \\
\hline $\mathrm{TP} 2-1$ & $40^{\circ} 49^{\prime} 41.34^{\prime \prime}$ & $14^{\circ} 06^{\prime} 19.46^{\prime \prime}$ & 8.0 & 0.69 & 99.3 & - & - & Coarse sand \\
\hline $\mathrm{TP} 2-2$ & $40^{\circ} 49^{\prime} 23.95^{\prime \prime}$ & $14^{\circ} 06^{\prime} 21.93^{\prime \prime}$ & 25.8 & 1.50 & 97.0 & 1.40 & 0.10 & Very fine sand \\
\hline $\mathrm{TP} 2-3$ & $40^{\circ} 48^{\prime} 42.91^{\prime \prime}$ & $14^{\circ} 06^{\prime} 29.06^{\prime \prime}$ & 34.0 & 6.72 & 91.8 & 1.32 & 0.15 & Fine sand \\
\hline TP3-1 & $40^{\circ} 49^{\prime} 05.98^{\prime \prime}$ & $14^{\circ} 07^{\prime} 50.41^{\prime \prime}$ & 7.5 & 0.67 & 99.3 & - & - & Medium sand \\
\hline TP3-2 & $40^{\circ} 48^{\prime} 53.02^{\prime \prime}$ & $14^{\circ} 07^{\prime} 46.26^{\prime \prime}$ & 23.8 & 5.10 & 94.9 & - & - & Fine sand \\
\hline TP3-3 & $40^{\circ} 48^{\prime} 33.38^{\prime \prime}$ & $14^{\circ} 07^{\prime} 38.47^{\prime \prime}$ & 38.0 & 2.89 & 96.1 & 0.88 & 0.12 & Fine sand \\
\hline ТP4-1 & $40^{\circ} 48^{\prime} 46.43^{\prime \prime}$ & $14^{\circ} 09^{\prime} 30.87^{\prime \prime}$ & 7.7 & 0.06 & 99.9 & - & - & Fine sand \\
\hline TP4-2 & $40^{\circ} 48^{\prime} 32.74^{\prime \prime}$ & $14^{\circ} 09^{\prime} 17.63^{\prime \prime}$ & 21.5 & 0.57 & 98.9 & 0.47 & 0.07 & Fine sand \\
\hline TP5-1 & $40^{\circ} 47^{\prime} 33.96^{\prime \prime}$ & $14^{\circ} 09^{\prime} 28.91^{\prime \prime}$ & 22.7 & 49.1 & 50.8 & - & - & Very fine gravel \\
\hline
\end{tabular}




\section{Results}

All the samples yielded both benthic foraminiferal and ostracod shells (no barren samples) (Tables 2-8). A total of 4262 foraminiferal individuals and 3607 ostracod valves were collected. The good state of preservation, the distribution data, and the presence of all developmental stages (in ostracods: different young instars and adults) suggested that the calcareous meiofaunal assemblages could be considered entirely autochthonous. The benthic foraminiferal assemblages included 142 species assigned to 74 genera; 127 ostracod species in 49 genera were recorded (Appendix 1; Figs. 2-3). Five benthic foraminiferal species and eight ostracod species were tentatively identified or left in open nomenclature and nine with affinitive status due to the absence of adult specimens, or because of poorly preserved shells. The good state of preservation, the distribution data, and the presence of all developmental stages (in ostracods: different young instars and adults) suggested that the calcareous meiofaunal assemblages could be considered entirely autochthonous.

Benthic foraminifers.

Six benthic foraminiferal species were present in all the samples, that is, Ammonia aberdoveyensis, Buccella granulata, Cibicides lobatulus, Elphidium crispum, Quinqueloculina seminulum and Triloculina schreiberiana. Assemblages were characterized by the genera Quinqueloculina (19 species) and Elphidium (10 species). Cibicides lobatulus was the most abundant species, with a Medium Relative Abundance (MRA) of $12.8 \%$, followed by Tretomphalus concinnus $(\mathrm{MRA}=5.54 \%)$, Siphonaperta aspera $(\mathrm{MRA}=$ $4.30 \%)$, Elphidium crispum $(\mathrm{MRA}=3.97 \%)$, Asterigerinata mamilla $(\mathrm{MRA}=3.75 \%)$ and $Q$. seminu$\operatorname{lum}(\mathrm{MRA}=3.53 \%)$.

The number of species (S) was between 17 and 82, with discrimination between the three coarse-grained samples $(\mathrm{TP} 2-1=$ coarse $\quad$ sand; $\quad$ TP3-1 = medium sand; TP5-1 = very fine gravel) and the remaining eight samples, all made of fine or very fine sands. The former displayed a S range from 17 to 48, with the mean value of 34.33 ; the eight fine-grained samples had $\mathrm{S}$ between 52 and 82 (mean value $=61.25$ ).

The number of specimens (I) showed a wide range, from 69 to 105,984. The three coarse-grained samples displayed a mean value of 484 , whereas a I mean value of 51,540 was recorded for the remaining samples.
The dominance (D) was between 0.04 and 0.20 , with high values in the samples TP2-1 $(\mathrm{D}=0.20)$ and TP5-1 $(\mathrm{D}=0.16)$ and low $(\mathrm{D}(0.06)$ the remaining ones.

TP2-1 and TP5-1 assemblages showed a Shannon diversity index $\left(\mathrm{H}^{\prime}\right)$ less than 3 ; in the other assemblages $H^{\prime}>3$. Mean $H^{\prime}$ is 3.28. Mean $H^{\prime}$ is 3.28. A similar trend was observed for equitability $(\mathrm{J})$, low in the samples TP2-1 and TP5-1 $(\mathrm{J}<0.8)$ and high $(\mathrm{J}>0.8)$ in the other samples.

Ostracods.

The most diversified genera were Semicytherura (18 species) and Xestoleberis (12 species). Characteristic species were Urocythereis margaritifera $[\mathrm{MRA}(\mathrm{MNI})=8.10 \% ;$ MRA $(\mathrm{TNV})=9.94 \%]$, Pon tocythere turbida $[\mathrm{MRA}(\mathrm{MNI})=6.00 \%$; $\operatorname{MRA}(\mathrm{TNV})=5.64 \%]$, Semicytherura rarecostata $[\mathrm{MRA}(\mathrm{MNI})=5.56 \% ; \mathrm{MRA}(\mathrm{TNV})=3.87 \%]$, Loxoconcha rhomboidea $[\mathrm{MRA}(\mathrm{MNI})=5.08 \%$; $\operatorname{MRA}(\mathrm{TNV})=4.83 \%]$ and Loxoconcha ovulata $[\mathrm{MRA}(\mathrm{MNI})=3.68 \% ; \mathrm{MRA}(\mathrm{TNV})=5.55 \%]$. Loxoconcha affinis $[\mathrm{MRA}(\mathrm{MNI})=3.45 \%$; $\mathrm{MRA}(\mathrm{TNV})=$ $3.64 \%]$, Xestoleberis dispar [MRA(MNI) $=2.93 \%$; $\operatorname{MRA}(\mathrm{TNV})=5.26 \%], \quad$ Xestoleberis communis $[\mathrm{MRA}(\mathrm{MNI})=2.25 \% ; \quad \mathrm{MRA}(\mathrm{TNV})=5.22 \%]$ and Aurila convexa $[\mathrm{MRA}(\mathrm{MNI})=1.93 \% ; \mathrm{MRA}(\mathrm{TNV})=$ $4.95 \%$ ] were considered accessory species.

The three samples with coarser granulometry (TP21, TP3-1, TP5-1) yielded relatively poor ostracod assemblages, showing low diversity and high dominance. Conversely, in the fine-grained samples, diversity and abundance were high and the dominance low.

Taxa richness (S) ranged from 4 to 12 in the coarsegrained samples and from 31 to 57 in the remaining ones. In the former samples, abundance (I) was between 9 and 27 (MNI) and between 18 and 40 (TNV); in the latter samples, the mean value of I was 2065.5 (MNI) and 7781 (TNV). Shannon index H' followed a similar trend: in TP2-1, TP3-1, TP5-1 mean H' (MNI) was 1.68 and medium H' (TNV) was 1.56 ; in the assemblages occurring in the fine-grained sediments, medium H' (MNI) was 3.35 and medium $\mathrm{H}^{\prime}$ (TNV) was 3.10.

Dominance (D) values were high in the assemblages of samples TP2-1, TP3-1, TP5-1 [D (MNI) range $=0.09-0.48 ; \mathrm{D}(\mathrm{TNV})$ range $=0.14-0.70]$; in the fine-grained samples the average $\mathrm{D}$ was 0.05 (MNI) and 0.07 (TNV). 


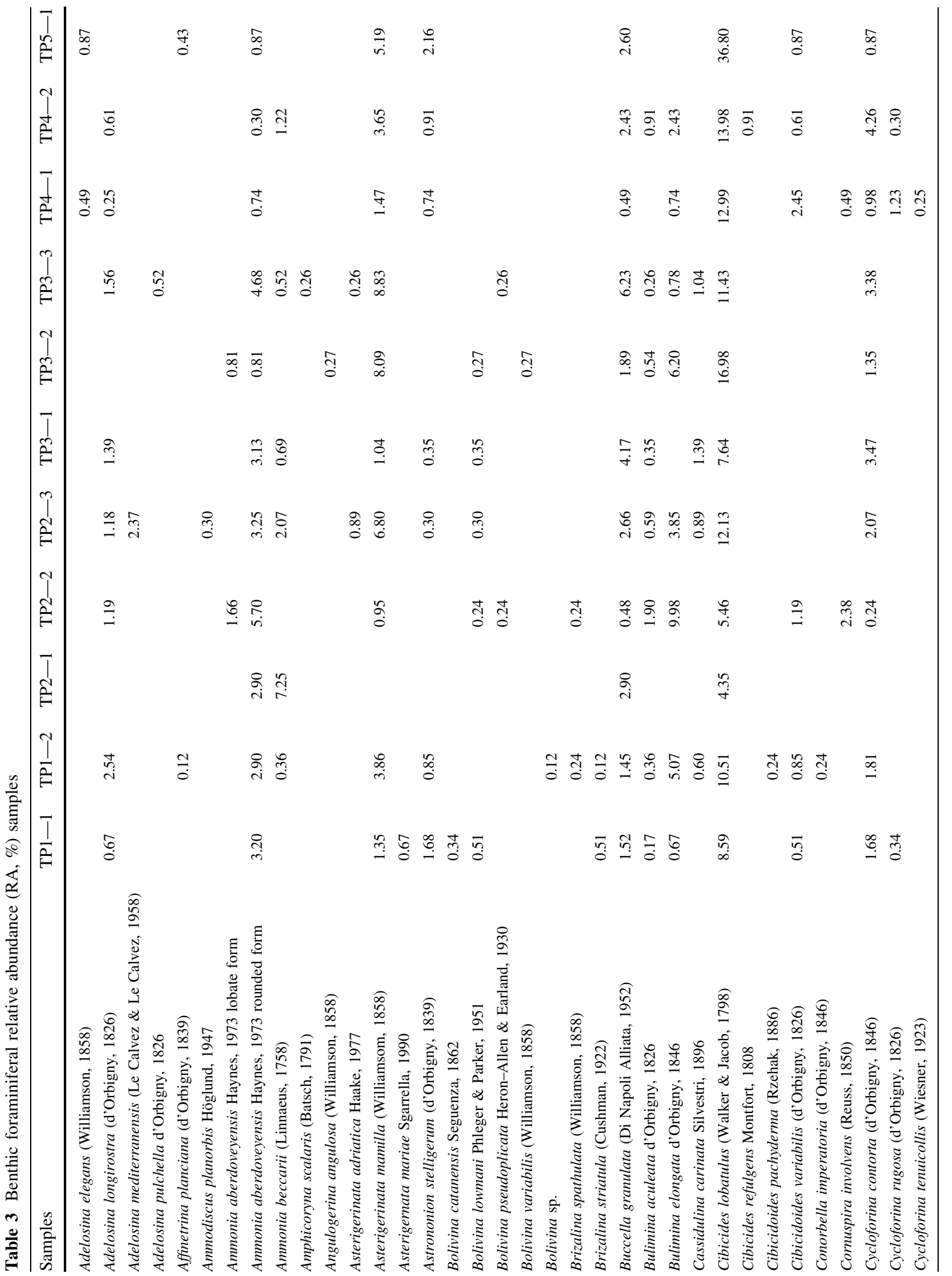




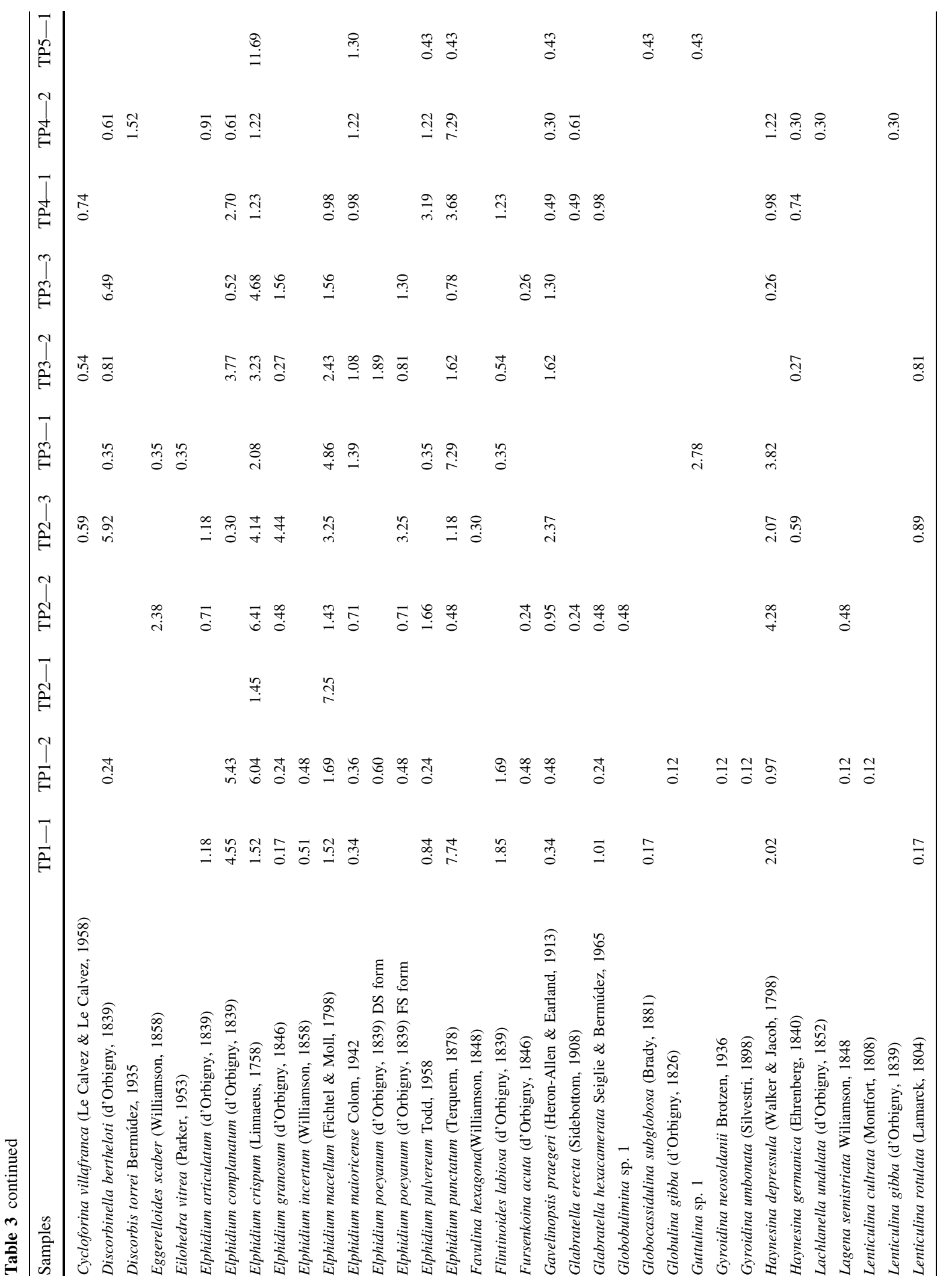




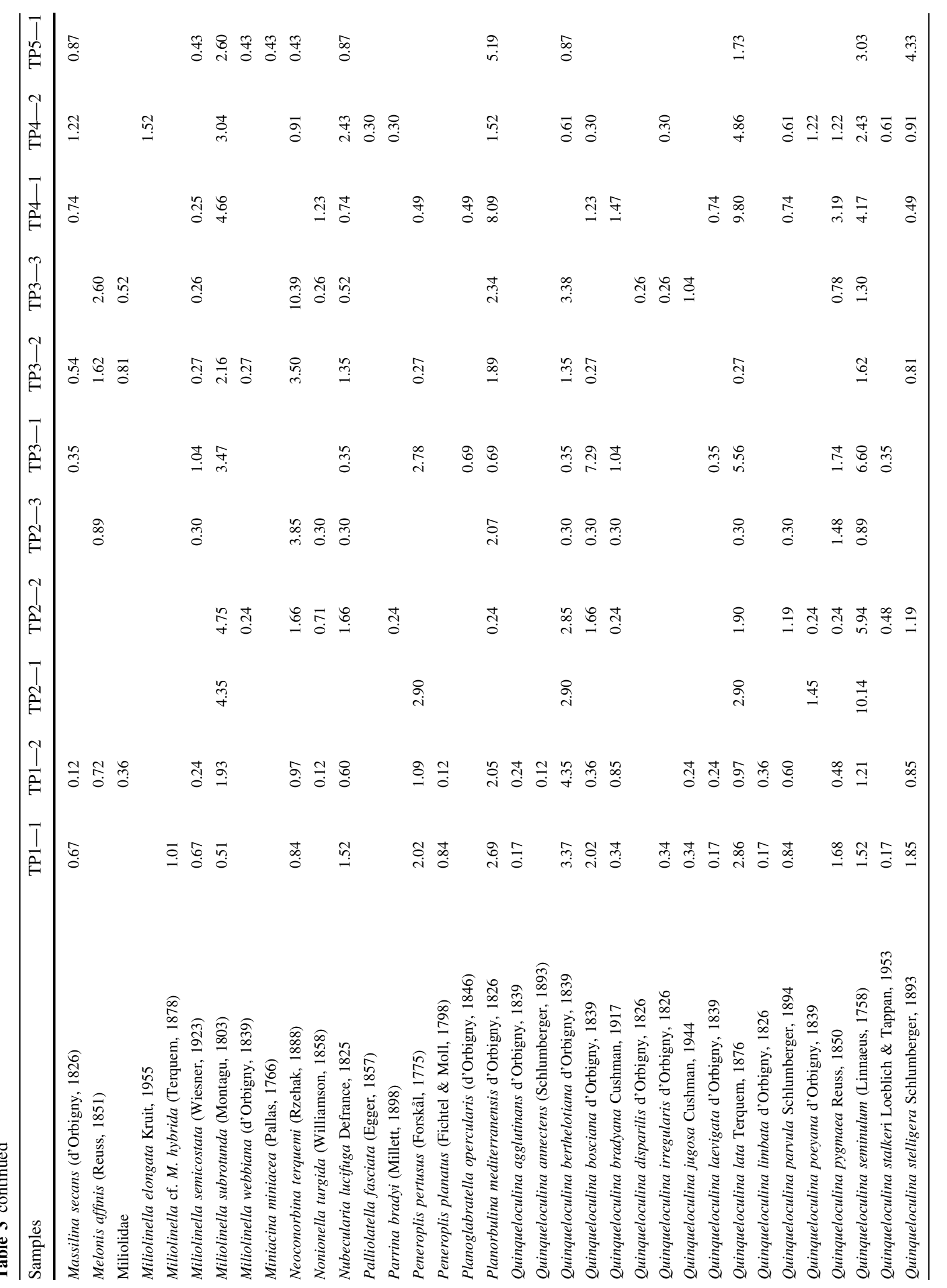




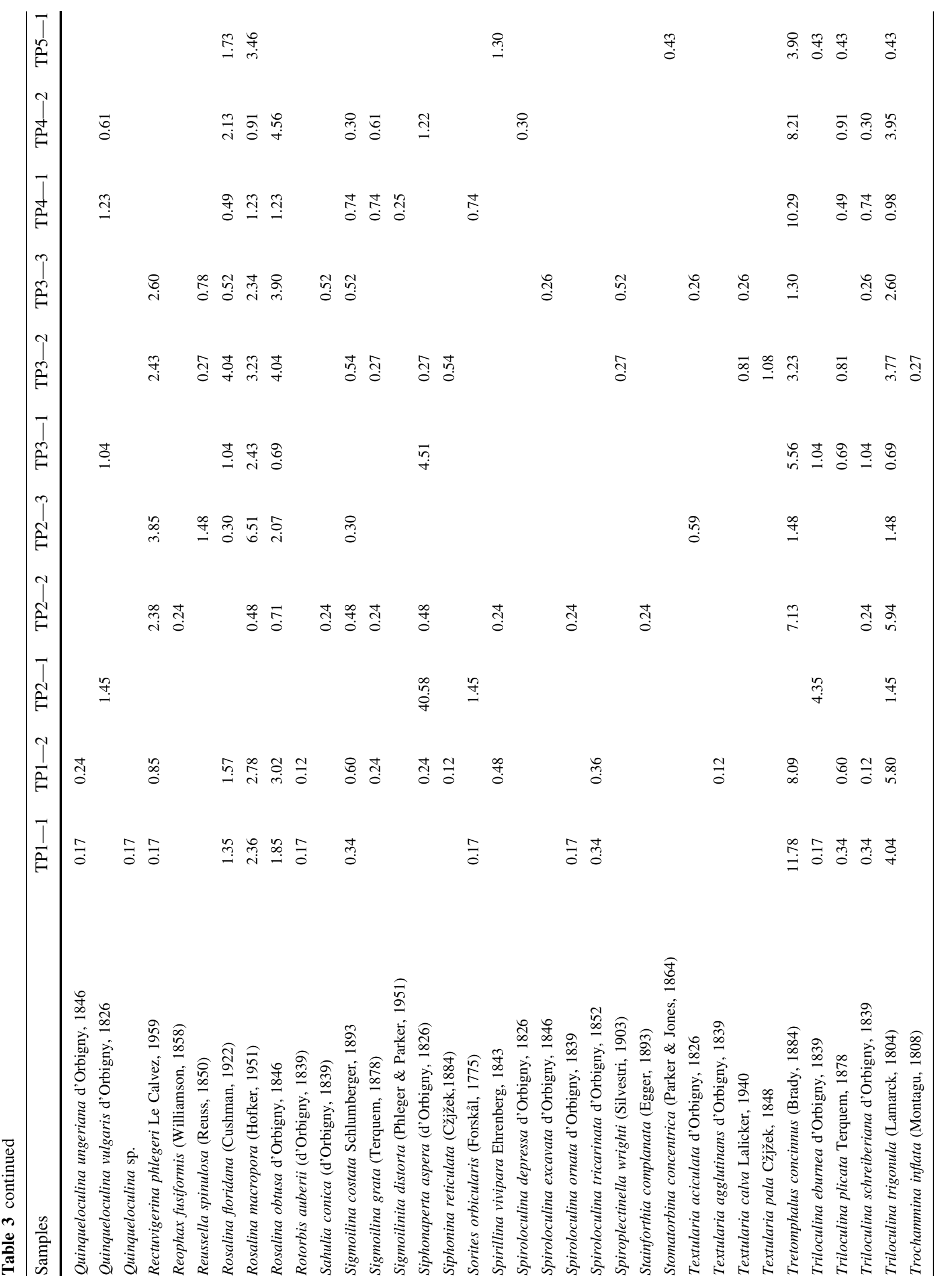


Equitability (J) ranged from 0.72 to 0.99 (MNI) and from 0.46 to 0.94 (TNV). The mean J values were 0.86 (MNI) and 0.79 (TNV).

Statistics.

The cluster analysis (Fig. 4) revealed two clusters of samples, obtained at a similarity cut-off level of 0.45. Cluster B consists of the coarse-grained samples TP2-1, TP3-1, and TP5-1, with low diversity-low abundance assemblages; cluster $A$ includes the remaining eight fine-grained (fine and very fine sands) samples, characterized by high-diversity-high abundance assemblages. The three sediment samples grouped in Cluster B, consisting of medium sand, coarse sand, and very fine gravel, showed low geochemical accumulation. Since both low meiofaunal abundance/diversity values and low pollutant concentrations are highly associated with grain size (v. Discussion section), a correlation analysis including all the samples would provide results strongly influenced by granulometry. Consequently, we opted for performing the Pearson's correlation coefficient analysis on the eight fine-grained samples included in Cluster A. Results of Pearson's correlation coefficient analysis using meiofaunal assemblages, depth, major and trace elements, total organic carbon, and polycyclic aromatic hydrocarbons (Table 9) are reported in Table 10. The foraminiferal species Cibicides lobatulus and Elphidium crispum are common in all the samples. The assemblages included in Cluster A are characterized by the foraminifers Tretomphalus concinnus, Asterigerinata mamilla, Triloculina trigonula, and Elphidium punctatum and by the ostracods Semicytherura rarecostata, Loxoconcha ovulata, $L$. rhomboidea, Aurila convexa, and Xestoleberis communis. In Cluster B, the foraminiferal species Siphonaperta aspera, Quinqueloculina seminulum, Elphidium macellum, and the ostracods Urocythereis margaritifera and Pontocythere turbida characterized the assemblages.Our results show that the anthropogenic impact in the infralittoral zone of the Gulf of Pozzuoli, recorded in the geochemical accumulation (v. Table 9), was not reflected by diversity indices of the calcareous meiofaunal assemblages. The present findings were compared with the results of a previous study by Moncharmont (1964), based on a sampling carried out in 1961 by Harbans S. Puri and the Stazione Zoologica Anton Dohrn, where the characteristic species of the infralittoral zone were Ammonia beccarii, A. mamilla, C. lobatulus and T. concinnus 


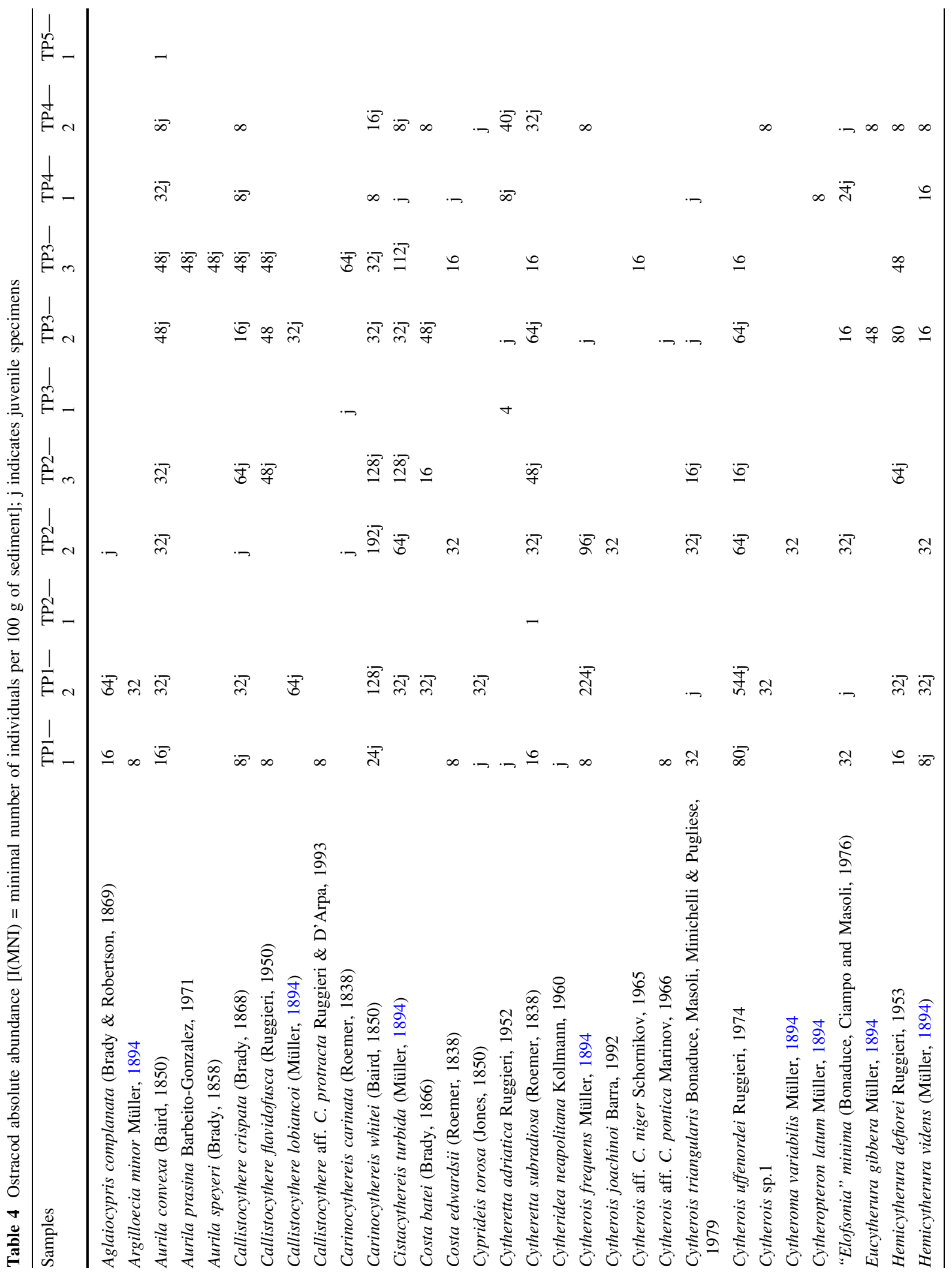




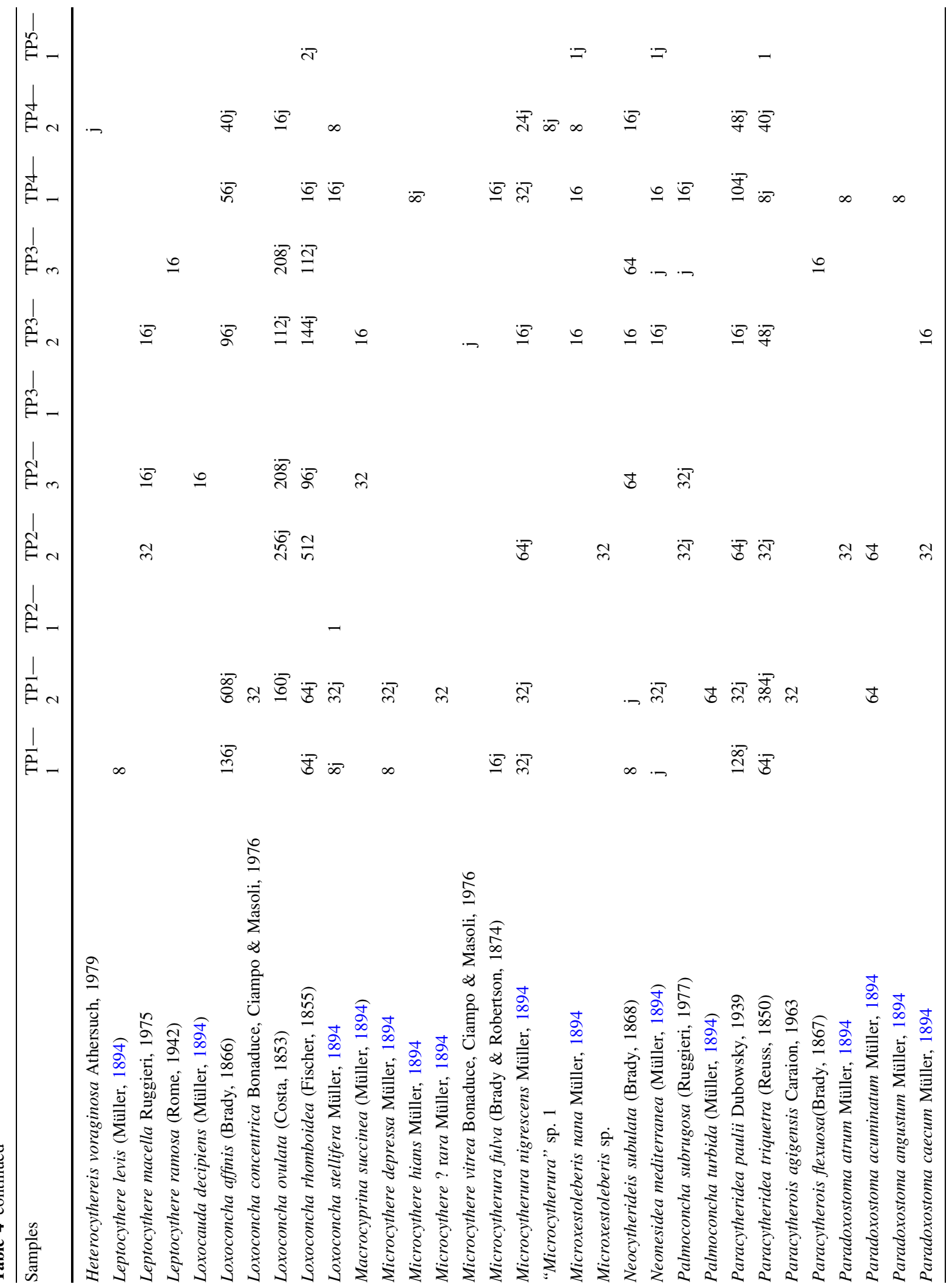




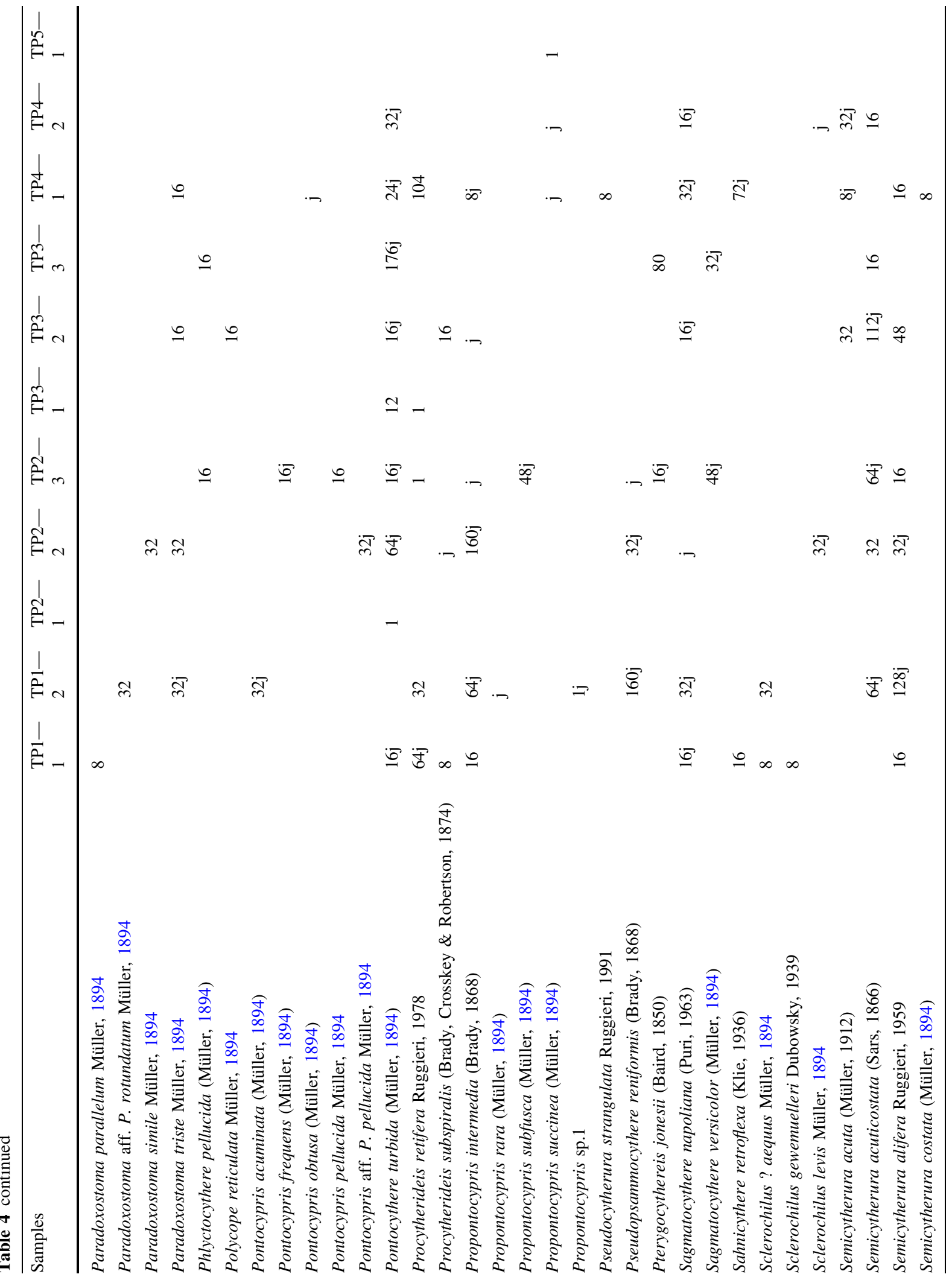




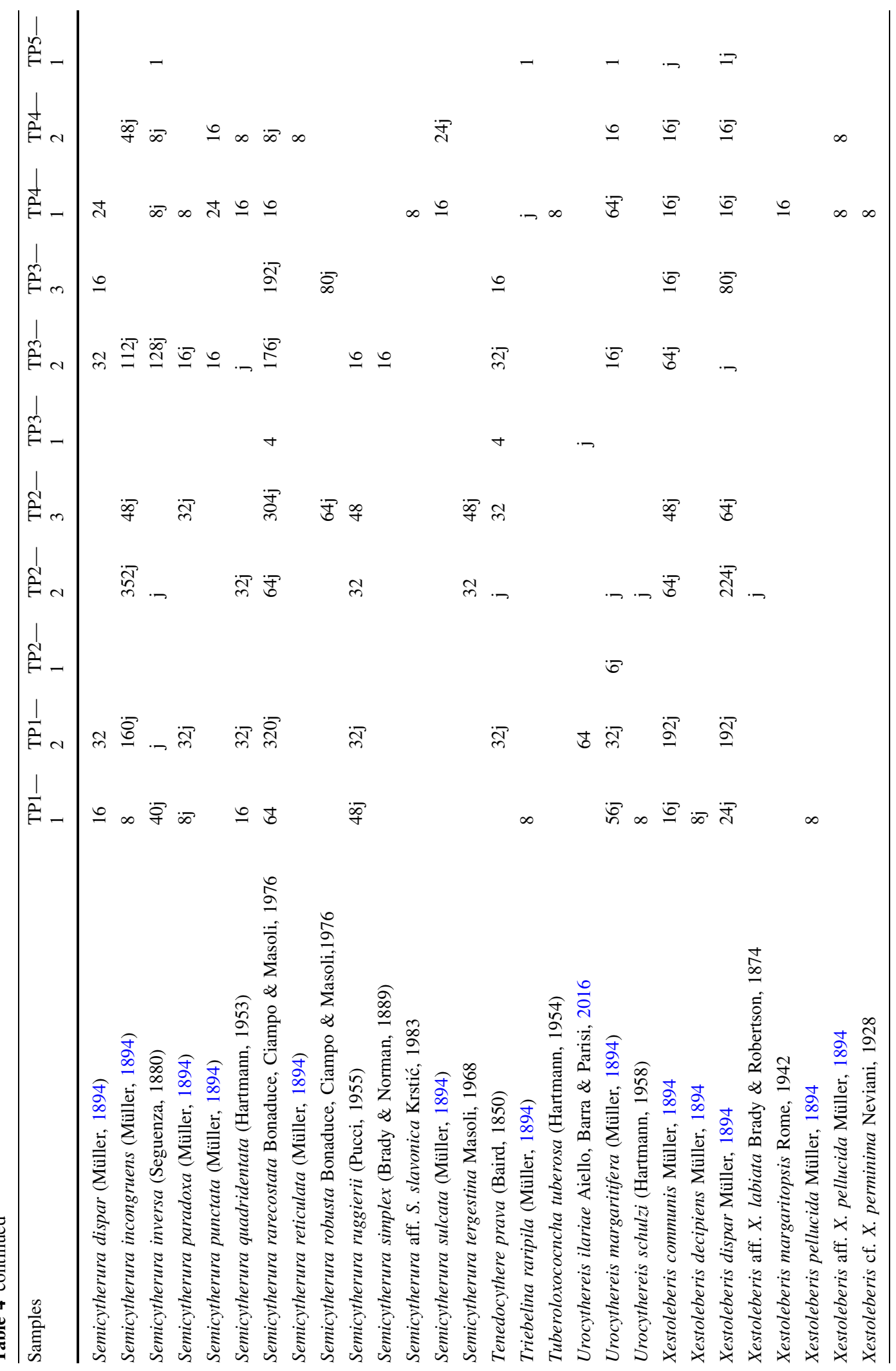




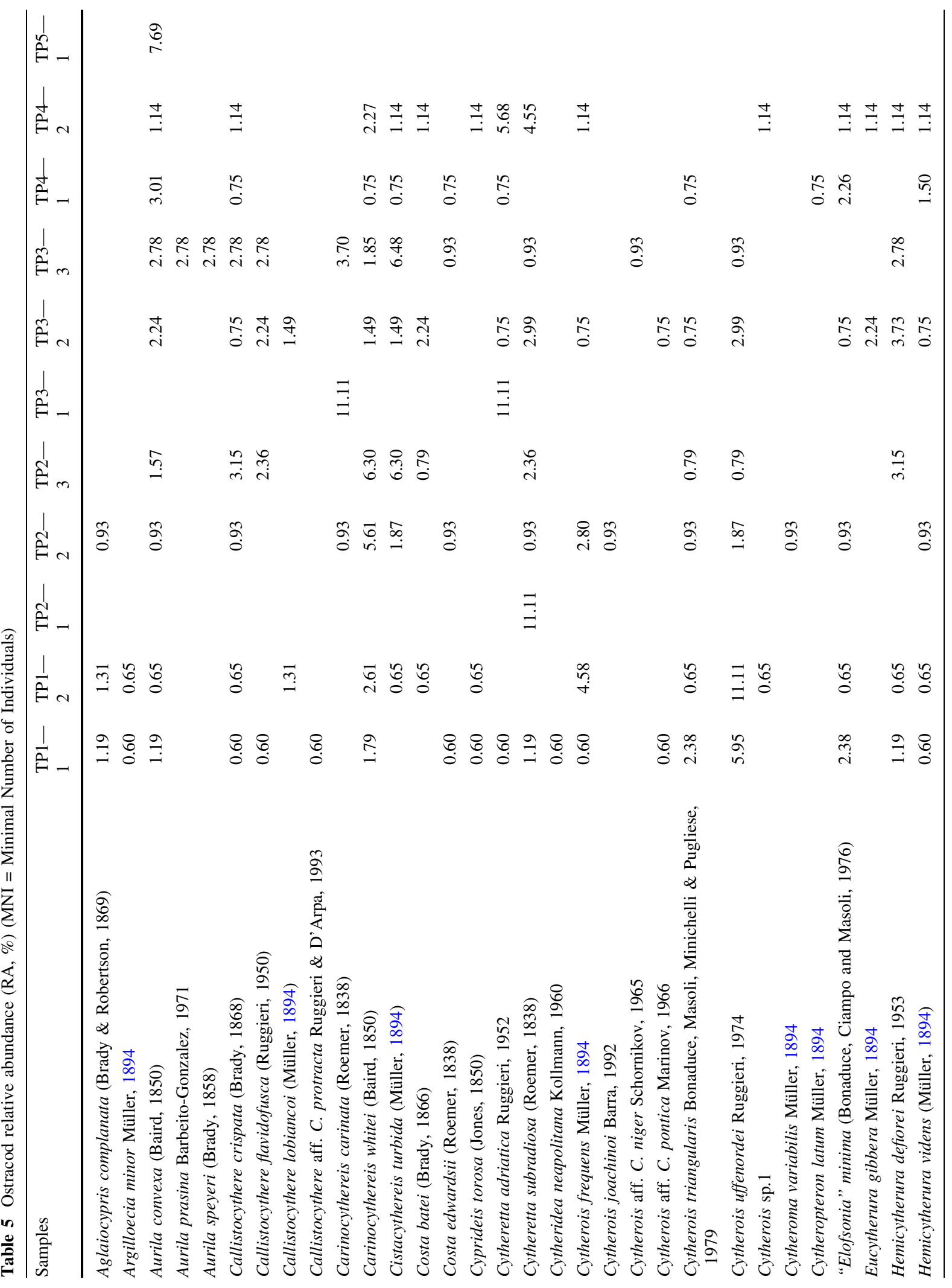




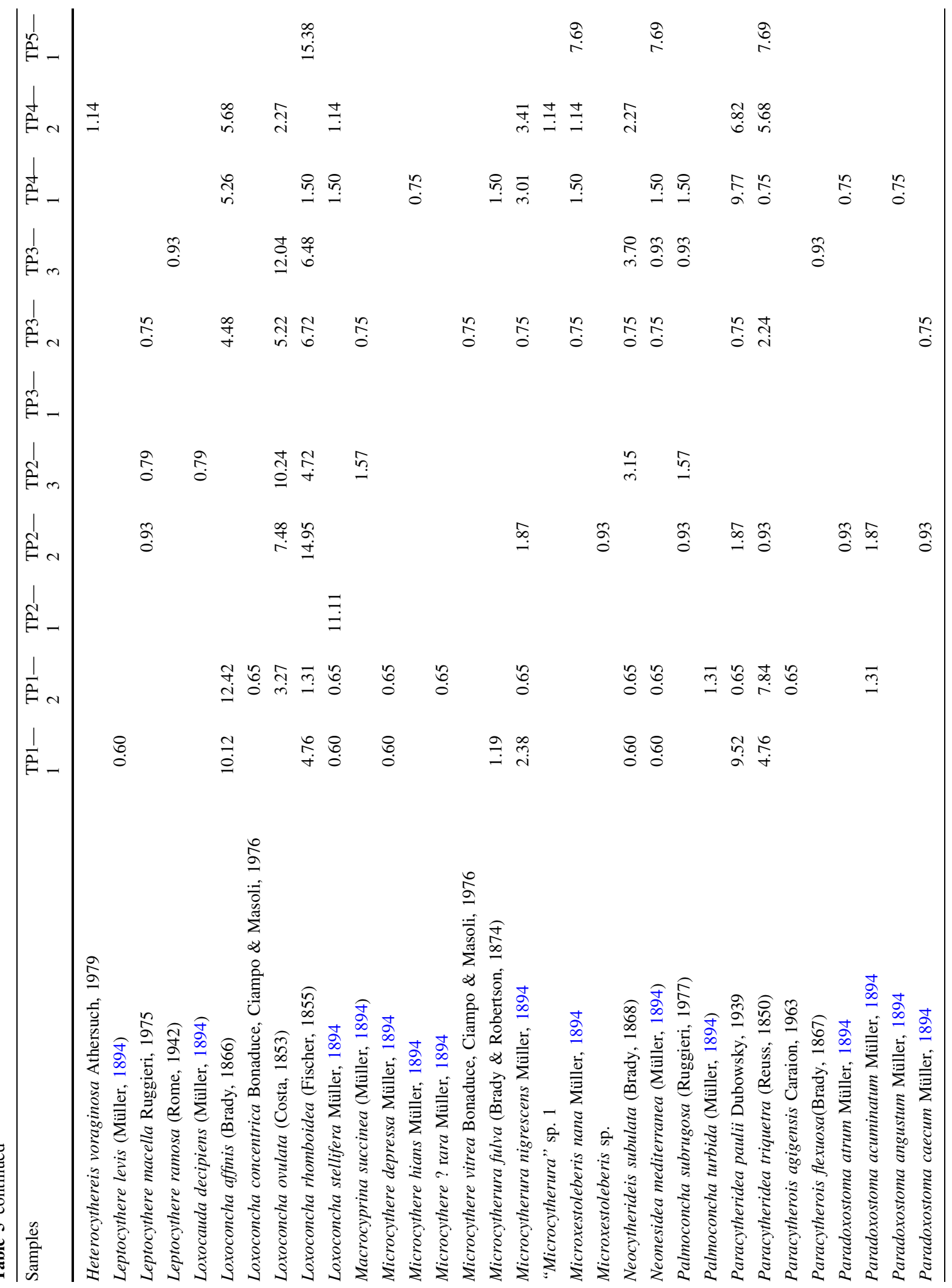




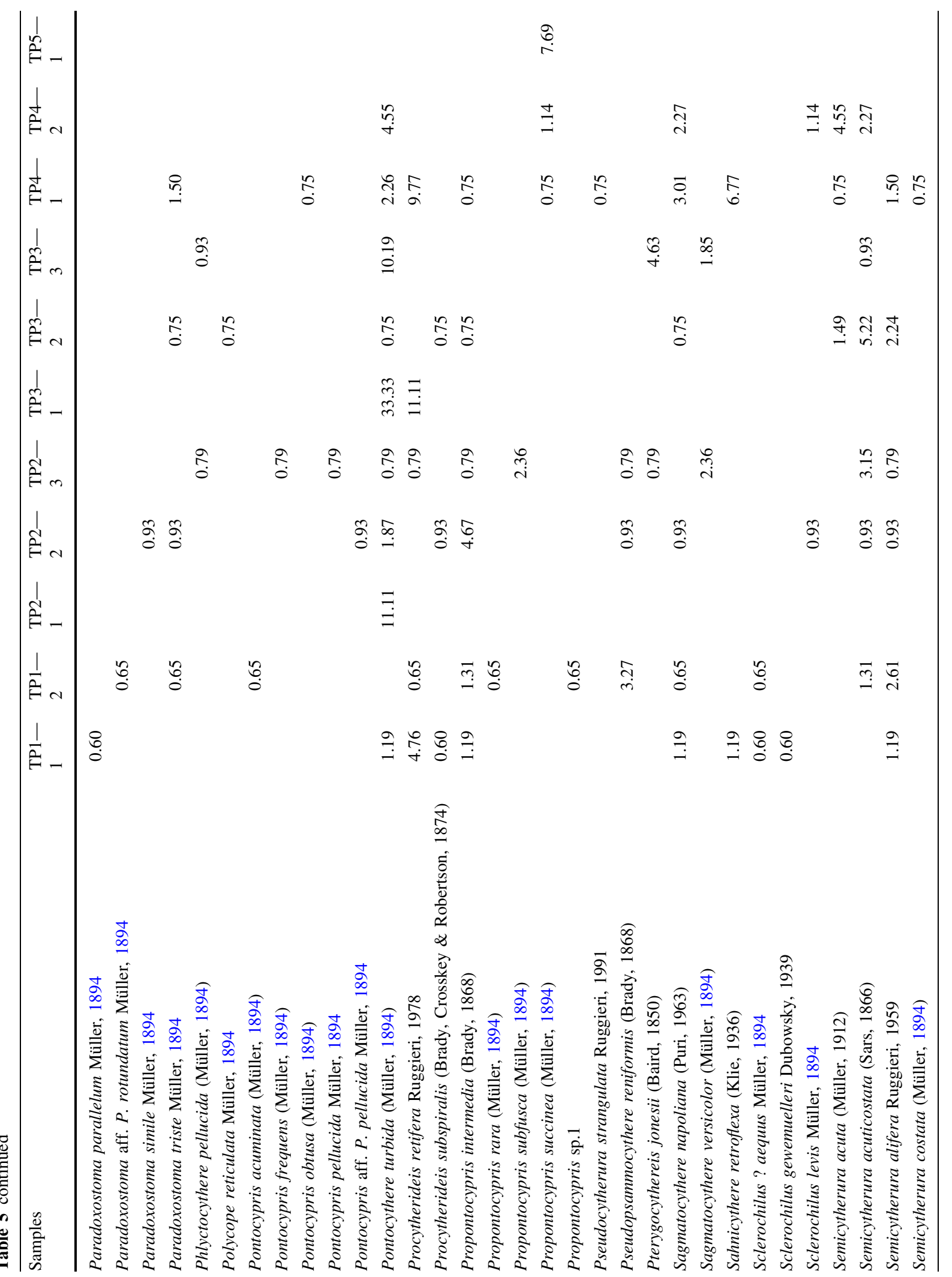




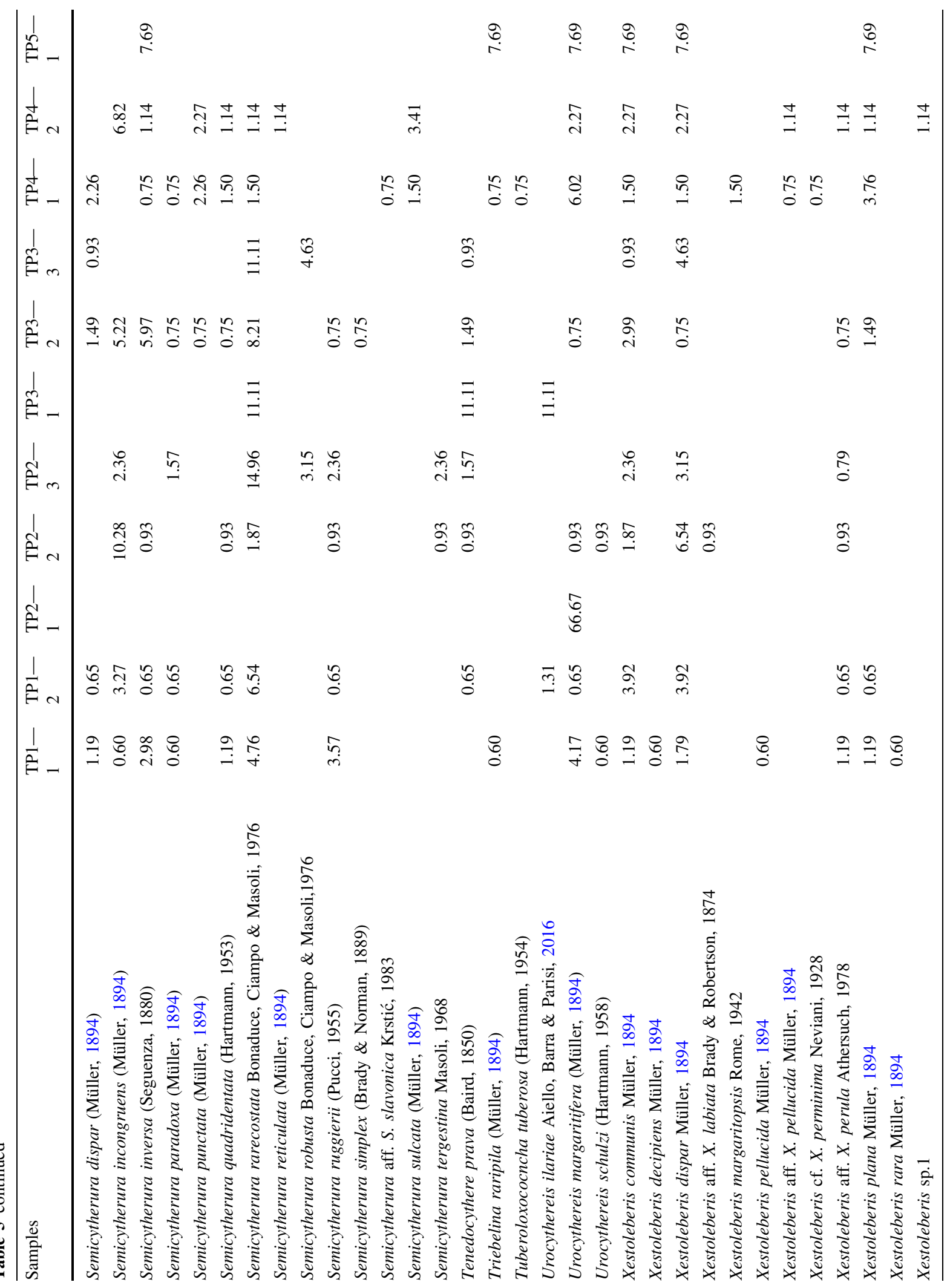




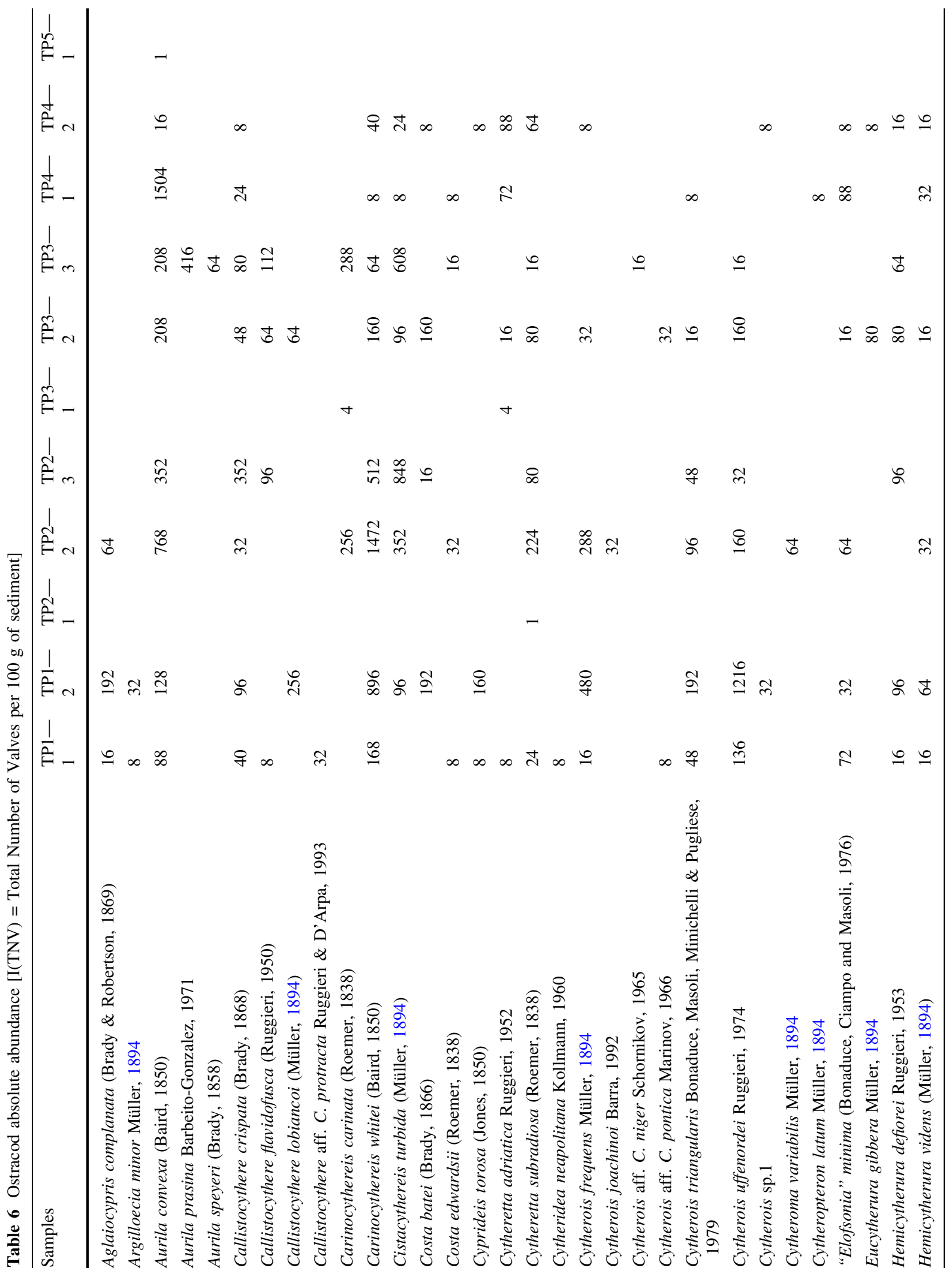




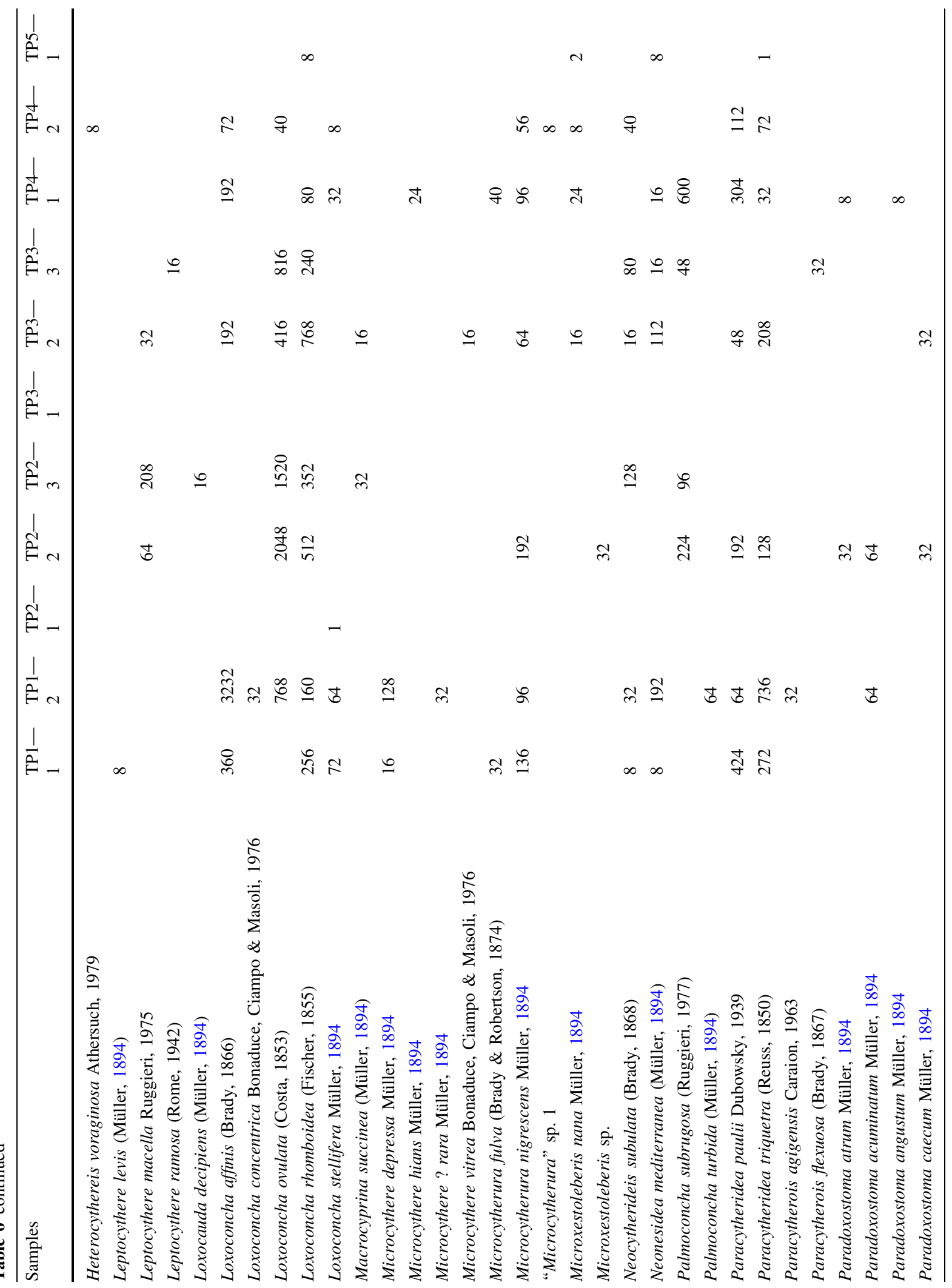




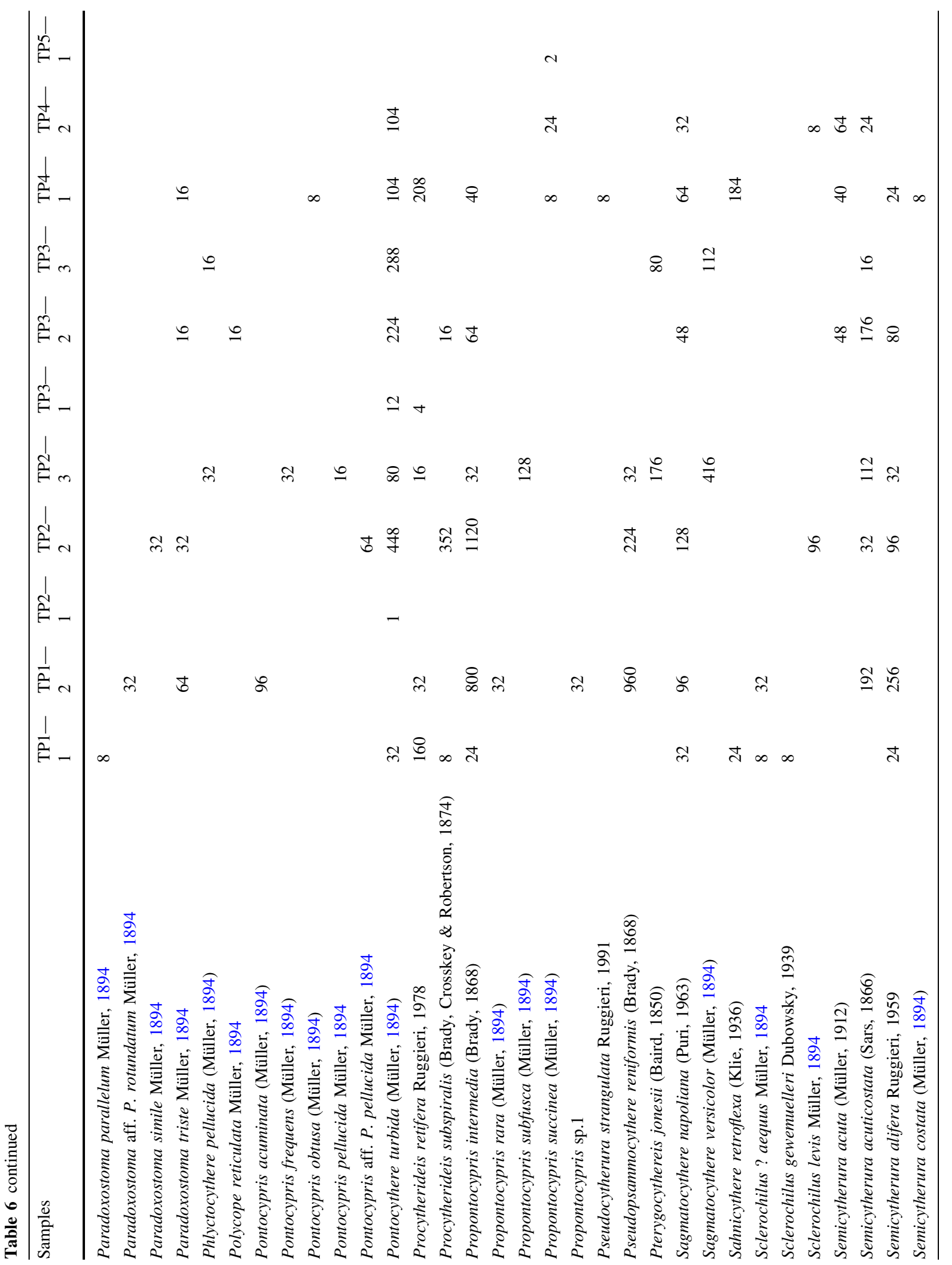




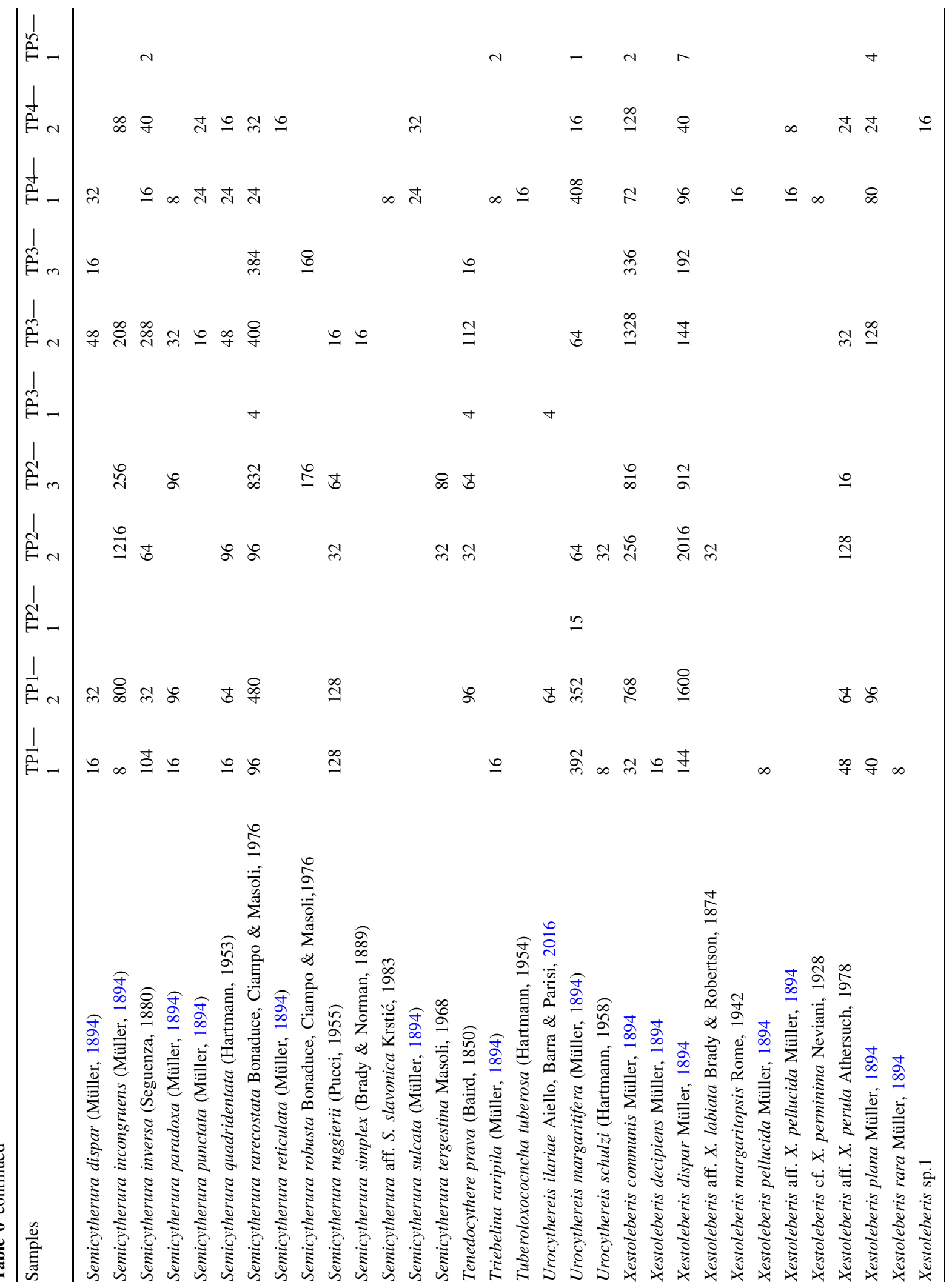




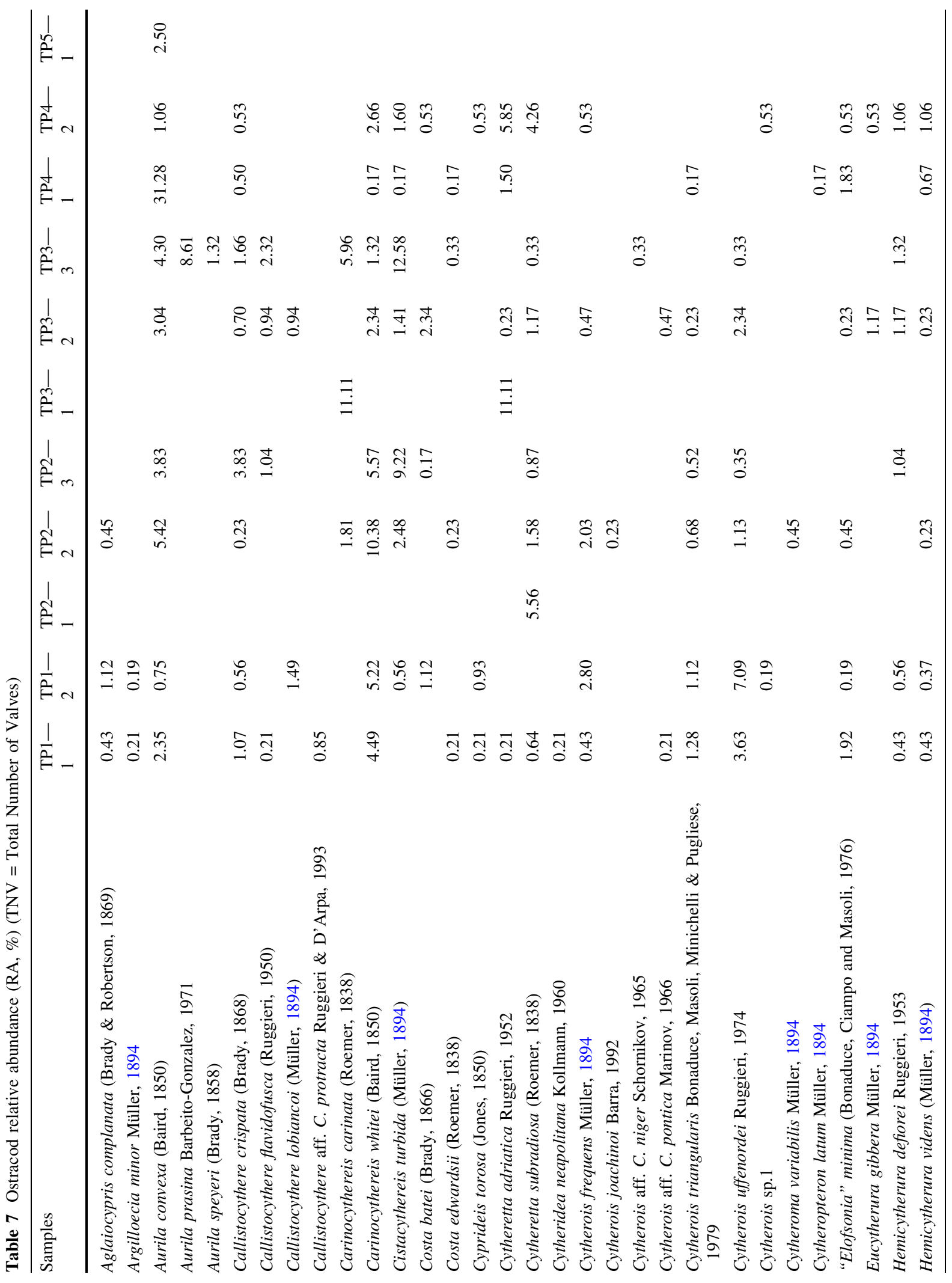




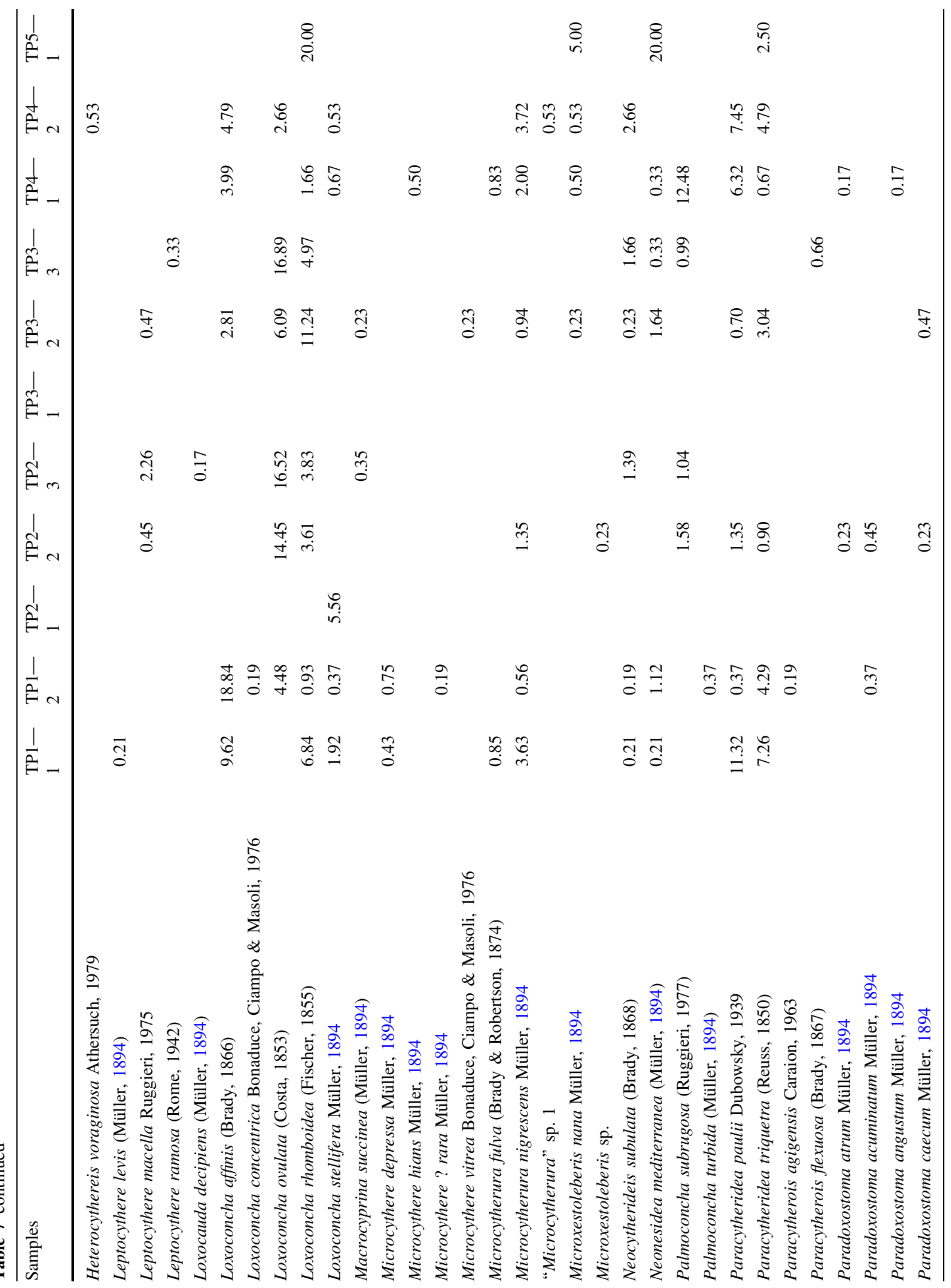




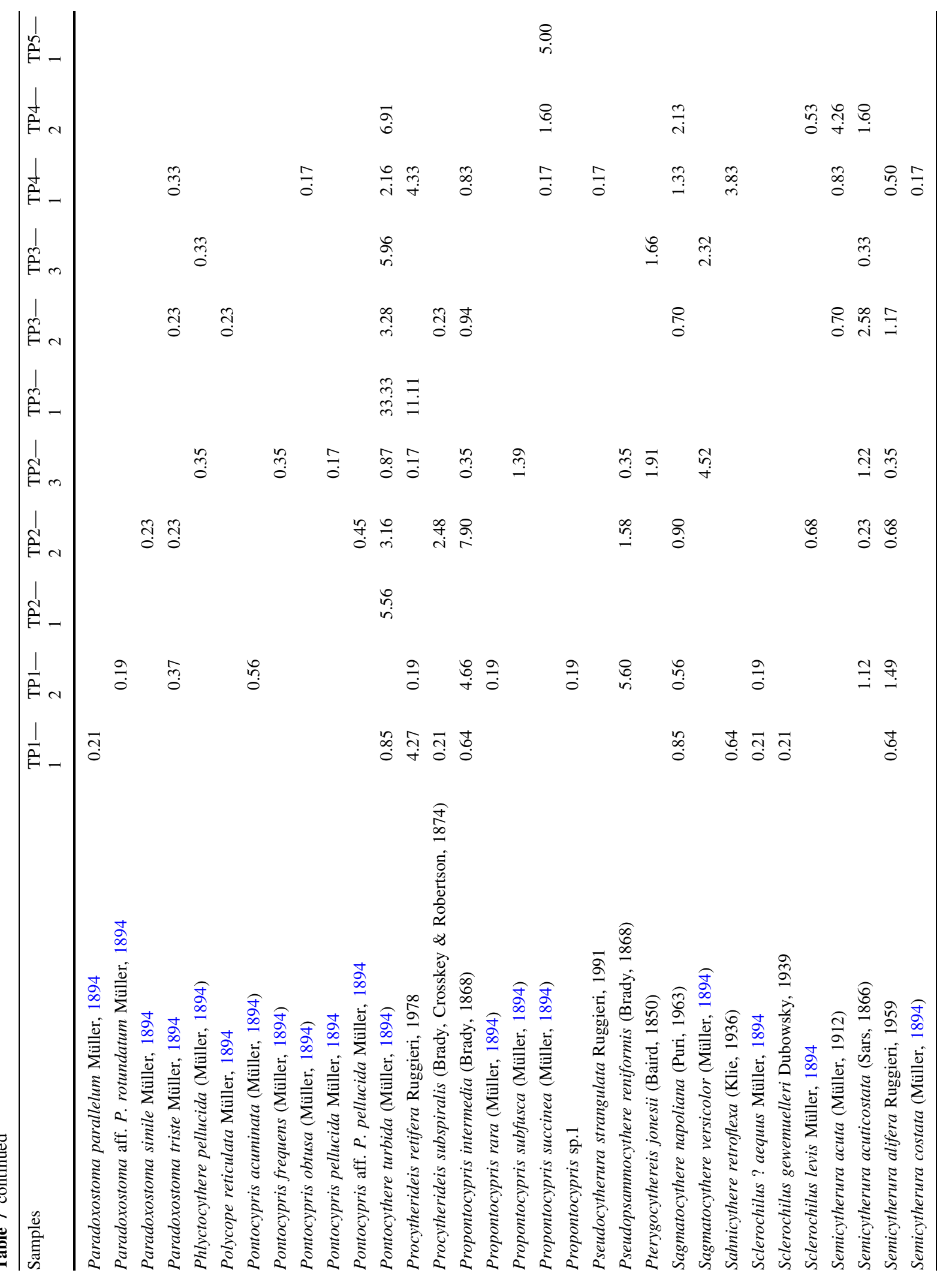




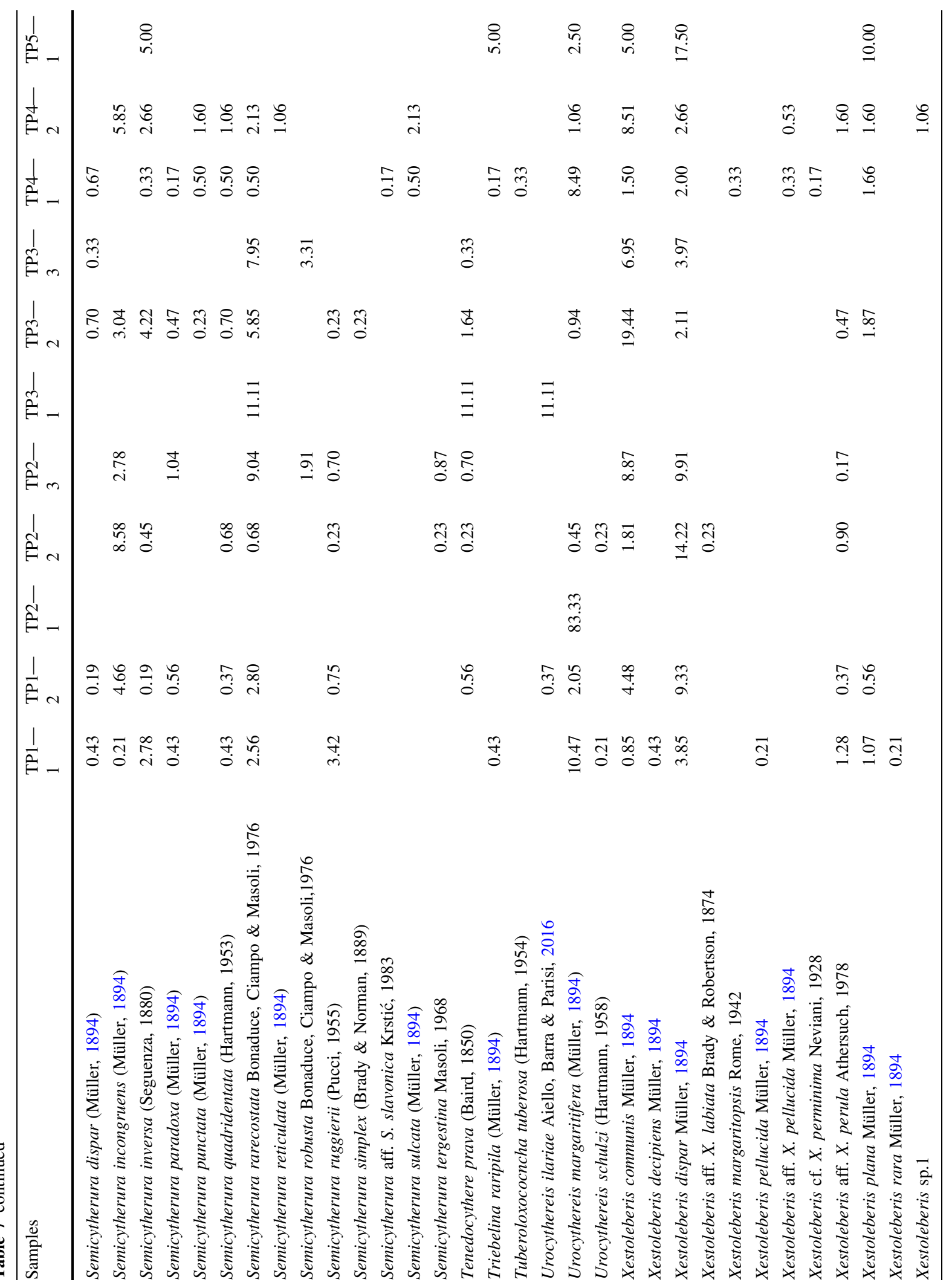


Table 8 Benthic foraminiferal and ostracod assemblage indices

\begin{tabular}{|c|c|c|c|c|c|c|c|c|c|c|c|}
\hline & TP1-1 & $\mathrm{TP} 1-2$ & $\mathrm{TP} 2-1$ & TP2 -2 & $\mathrm{TP} 2-3$ & TP3-1 & TP3-2 & TP3-3 & TP4-1 & TP4-2 & TP5-1 \\
\hline \multicolumn{12}{|l|}{ Foraminifers } \\
\hline Taxa (S) & 71 & 82 & 17 & 63 & 52 & 48 & 56 & 53 & 55 & 58 & 38 \\
\hline Individuals (I) & 19,008 & 105,984 & 69 & 26,944 & 43,264 & 1152 & 94,976 & 98,560 & 13,056 & 10,528 & 231 \\
\hline Dominance (D) & 0.04 & 0.04 & 0.20 & 0.04 & 0.04 & 0.04 & 0.06 & 0.05 & 0.06 & 0.05 & 0.16 \\
\hline Shannon (H') & 3.64 & 3.66 & 2.21 & 3.52 & 3.45 & 3.41 & 3.42 & 3.32 & 3.39 & 3.51 & 2.60 \\
\hline Equitability (J) & 0.85 & 0.83 & 0.78 & 0.85 & 0.87 & 0.88 & 0.85 & 0.84 & 0.85 & 0.86 & 0.72 \\
\hline \multicolumn{12}{|l|}{ Ostracod MNI } \\
\hline Taxa $(\mathrm{S})$ & 57 & 57 & 4 & 50 & 39 & 7 & 54 & 31 & 52 & 44 & 12 \\
\hline Individuals (I) & 1330 & 4710 & 9 & 3114 & 1972 & 27 & 2009 & 1698 & 1022 & 669 & 13 \\
\hline Dominance (D) & 0.04 & 0.05 & 0.48 & 0.07 & 0.06 & 0.27 & 0.04 & 0.06 & 0.04 & 0.04 & 0.09 \\
\hline Shannon (H') & 3.56 & 3.38 & 1.00 & 3.21 & 3.20 & 1.58 & 3.50 & 3.02 & 3.49 & 3.47 & 2.46 \\
\hline Equitability (J) & 0.88 & 0.84 & 0.72 & 0.82 & 0.87 & 0.81 & 0.88 & 0.88 & 0.88 & 0.92 & 0.99 \\
\hline \multicolumn{12}{|l|}{ Ostracod TNV } \\
\hline Individuals (I) & 3744 & 17,152 & 18 & 14,176 & 9200 & 36 & 6832 & 4832 & 4808 & 1504 & 40 \\
\hline Dominance (D) & 0.06 & 0.07 & 0.70 & 0.07 & 0.07 & 0.19 & 0.07 & 0.08 & 0.13 & 0.04 & 0.14 \\
\hline Shannon (H') & 3.28 & 3.21 & 0.63 & 3.06 & 2.97 & 1.83 & 3.26 & 2.84 & 2.77 & 3.43 & 2.21 \\
\hline Equitability (J) & 0.81 & 0.79 & 0.46 & 0.78 & 0.81 & 0.94 & 0.82 & 0.83 & 0.70 & 0.91 & 0.89 \\
\hline
\end{tabular}

(splitted by Moncharmont in $T$. concinnus and Rosalina globularis); conversely, $Q$. seminulum, $S$. aspera, Bulimina elongata were very rare. Our data suggested that $Q$. seminulum and B. elongata, stresstolerant species (Aiello et al., 2018; Debenay et al., 2009), and $S$. aspera may have increased their abundance in the last decades.

The 1961 sampling campaign also provided bottom sediments of the adjacent Gulf of Naples. Their ostracofaunas were analyzed by Puri et al. (1964). In the infralittoral zone, the ostracod assemblages were dominated by Aurila, Urocythereis, Carinocythereis, Costa and Pontocythere (Cushmanidea in Puri et al., 1964) species, Tenedocythere prava (= Quadracythere (?) prava plus «Cythereis» polygonata, the latter name including the juveniles, in Puri et al., 1964) and $S$. incongruens. In the present infralittoral ostracofauna of the Gulf of Pozzuoli U. margaritifera and $P$. turbida are very common, but overall the assemblages are not dominated by trachyleberid species, being characterized by the genera Loxoconcha and Xestoleberis and by the species $S$. rarecostata.

It can be hypothesized that industrial and urban contaminants caused a meiofaunal change, more apparent in ostracod than in benthic foraminifers. Conversely, the high-diversity and low-dominance values showed that in oligotrophic and well- oxygenated waters (e.g., Hyams-Kaphzan et al., 2009 , in a coastal area under the influence of sewage sludge with organic matter input), the diversity indices were not negatively influenced by the high concentration of pollutants in bottom sediments.

The sensitivity of ostracod and benthic foraminifers was also displayed by statistical analysis. Noteworthy correlations between ostracod dominance and sediment contaminants (polycyclic aromatic hydrocarbons, rare earth elements) encourage the use of calcareous meiofaunal assemblages as environmental bioindicators. The analysis confirmed the results of previous investigations, such as the tolerance of $Q$. lata to high heavy metal concentrations (Romano et al., 2009) testified by high correlations $(\geq 0.76)$ with $\mathrm{Ni}, \mathrm{Pb}$, and $\mathrm{Zn}$. Quinqueloculina lata was considered a pollution-tolerant species, by Elshanawany et al. (2011; 2018) and by Romano et al. (2013) in environment under strong anthropogenic pressure. The study of Mangoni et al. (2016) showed a correlation of this species with high concentrations of inorganic nutrients.

The strong anticorrelations $(\leq-0.80)$ between both TNV and MNI abundances of the typical shallow marine (Aiello et al., 2016, 2018) species P. paulii and $U$. margaritifera, and water depth suggested the preferences of these taxa for the uppermost part of 

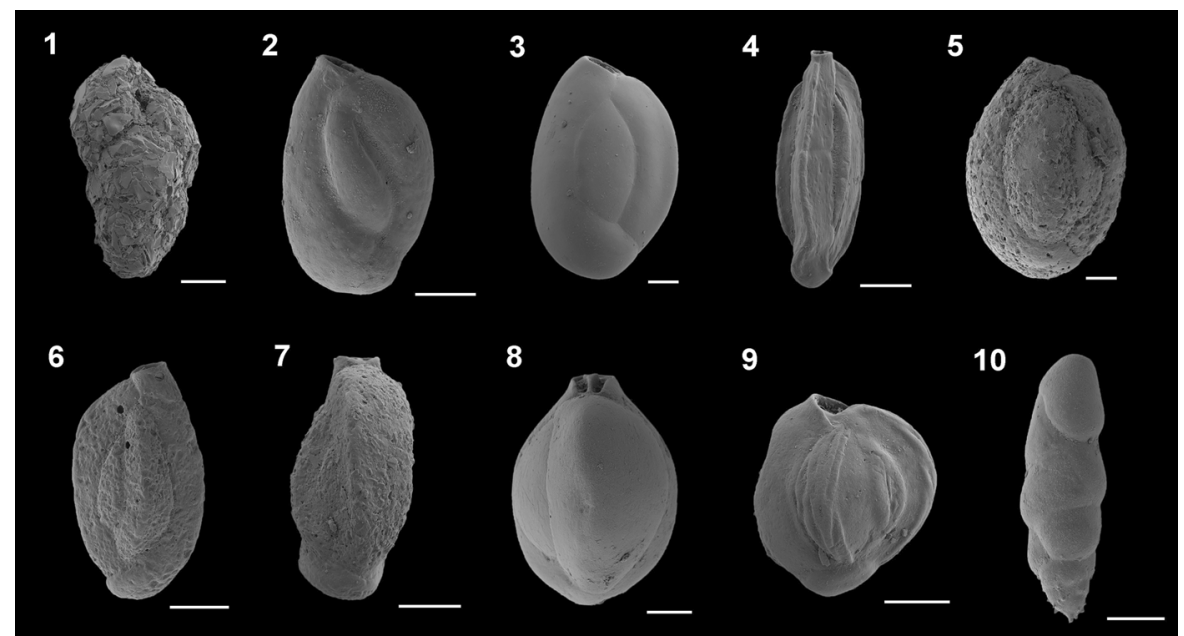

11

12

13

14
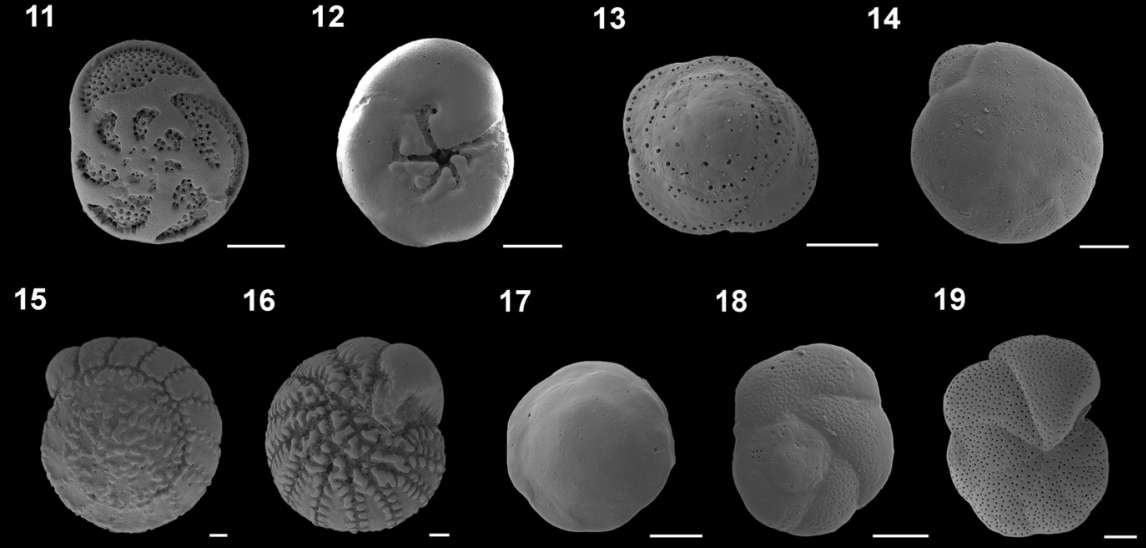

16

17

18

19

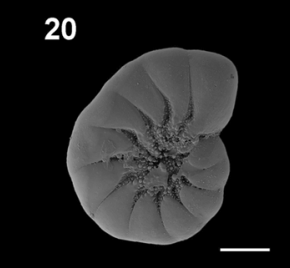

21

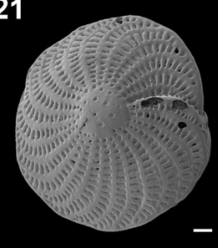

22

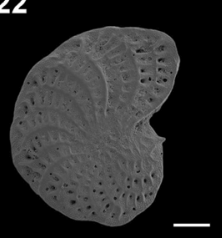

23

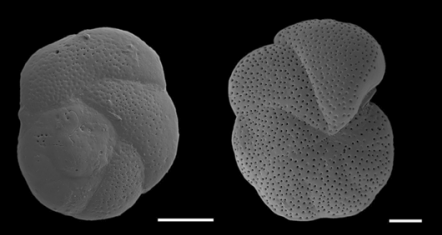

Fig. 21 Eggerelloides scaber (Williamson, 1858), lateral view, sample TP2-2, ABMC 2019/042 2 Quinqueloculina lata Terquem, 1876, four chamber side, sample TP1-1, ABMC 2019/054 3 Quinqueloculina seminulum (Linnaeus, 1758), four chamber side, sample TP2-2, ABMC 2019/045 4 Quinqueloculina stelligera Schlumberger, 1893, peripheral view, sample TP1-2, ABMC 2019/044 5 Siphonaperta aspera (d'Orbigny, 1826), side view, sample TP2-1, ABMC 2019/040 6 Cycloforina contorta (d'Orbigny, 1846), four chamber side, sample TP1-2, ABMC 2019/058 7 Cycloforina contorta (d'Orbigny, 1846), peripheral view, sample TP1—2, ABMC 2019/059 8 Triloculina trigonula (Lamarck, 1804), peripheral view, sample TP1-2, ABMC 2019/046 9 Miliolinella semicostata (Wiesner, 1923), side view, sample TP1-1, ABMC 2019/048 10 Bulimina elongata d'Orbigny, 1846, lateral view, sample TP3 —2, ABMC 2019/047 11 Rosalina macropora (Hofker, 1951), spiral side, sample TP12, ABMC 2019/055 12 Rosalina macropora (Hofker, 1951), umbilical side, sample TP1-2, ABMC 2019/056 13 Asterigerinata mamilla (Williamsom, 1858), spiral side, sample TP1-2, ABMC 2019/051 14 Ammonia aberdoveyensis Haynes, 1973, spiral side, sample TP1—1, ABMC 2019/039 15 Ammonia beccarii (Linnaeus, 1758), spiral side, sample TP2—3, ABMC 2019/060 16 Ammonia beccarii (Linnaeus, 1758), umbilical side, sample TP23, ABMC 2019/061 17 Buccella granulata (Di Napoli Alliata, 1952), spiral side, sample TP2-3, ABMC 2019/043 18 Tretomphalus concinnus (Brady, 1884), spiral side, sample TP1-1, ABMC 2019/052 19 Cibicides lobatulus (Walker \& Jacob, 1798), umbilical side, sample TP1—2, ABMC 2019/053 20 Haynesina depressula (Walker \& Jacob, 1798), side view, sample TP1-1, ABMC 2019/050 21 Elphidium crispum (Linnaeus, 1758), side view, sample TP2 - 3, ABMC 2019/041 22 Elphidium maioricense Colom, 1942, side view, sample TP3-2, ABMC 2019/049 23 Planorbulina mediterranensis d'Orbigny, 1826, unattached side, sample TP3-2, ABMC 2019/057 Scale bar $100 \mu \mathrm{m}$ 


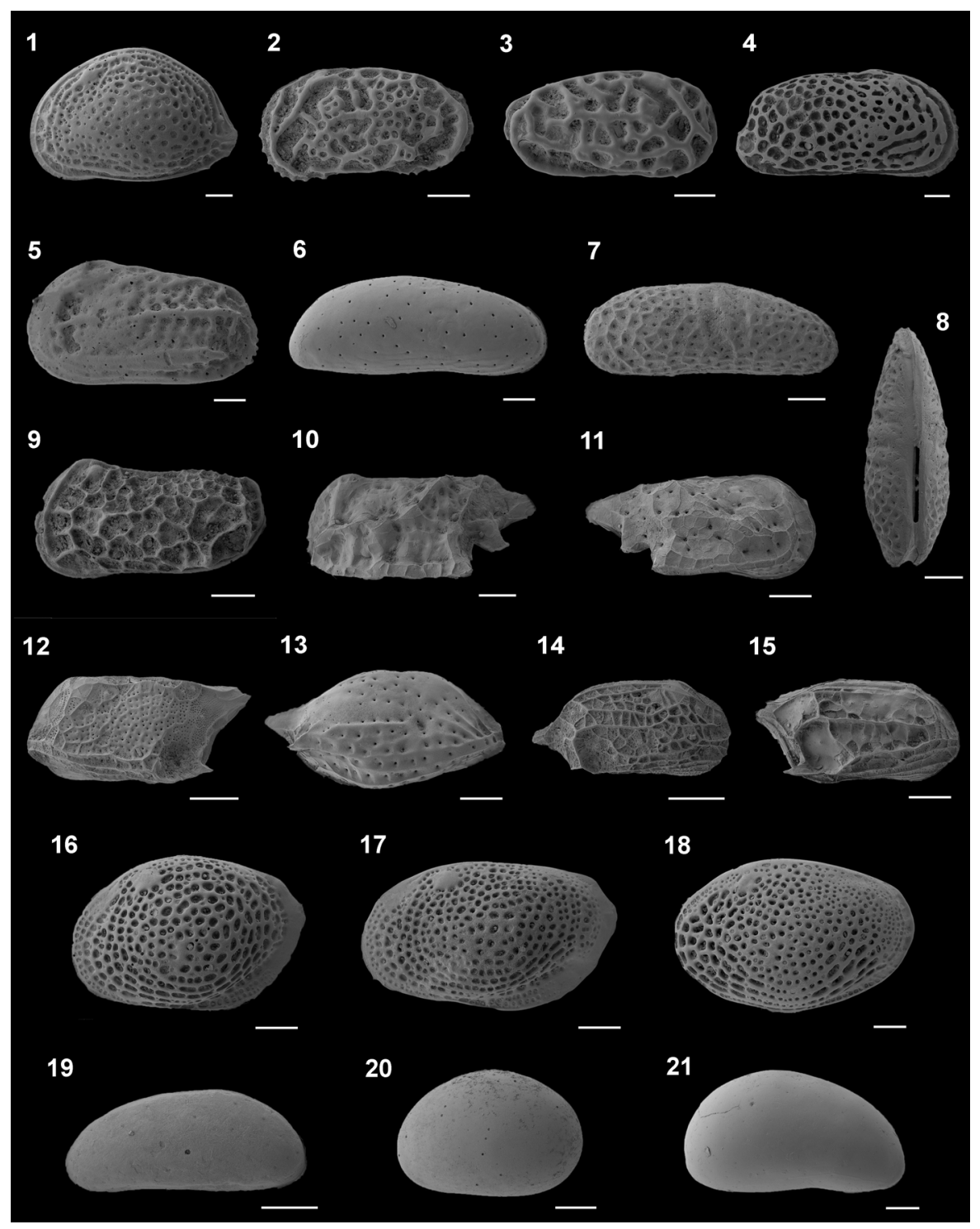

Fig. 31 Aurila convexa (Baird, 1850), left valve, sample TP2-3, ABMC 2019/065 2 Callistocythere lobiancoi (Müller, 1894), left valve, sample TP1-2, ABMC 2019/078 3Callistocythere flavidofusca (Ruggieri, 1950), right valve, sample TP2-3, ABMC 2019/067 4 Urocythereis margaritifera (Müller, 1894), right valve, sample TP2—1, ABMC 2019/068 5 Cistacythereis turbida (Müller, 1894), left valve, sample TP2-3, ABMC 2019/074 6 Pontocythere turbida (Müller, 1894), right valve, sample TP2-2, ABMC 2019/072 7 Procytherideis retifera Ruggieri, 1978, right valve, sample TP1-1, ABMC 2019/081 8 Procytherideis retifera Ruggieri, 1978, carapace in dorsal view, sample TP1-1, ABMC 2019/082 9 Sagmatocythere napoliana, left valve, sample TP3-2, ABMC 2019/075 10 Paracytheridea triquetra (Reuss, 1850), left valve, sample TP1-1, ABMC 2019/066 11 Paracytheridea paulii Dubowsky, 1939, right valve, sample TP1-1, ABMC 2019/062 12 Semicytherura robusta Bonaduce,
Ciampo \& Masoli,1976, left valve, sample TP2-3, ABMC 2019/077 13 Semicytherura incongruens (Müller, 1894), right valve, sample TP2-2, ABMC 2019/070 14 Semicytherura rarecostata Bonaduce, Ciampo \& Masoli, 1976, right valve, sample TP1-2, ABMC 2019/076 15 Semicytherura ruggierii (Pucci, 1955), right valve, sample TP1-1, ABMC 2019/080 16 Loxoconcha affinis (Brady, 1866), left valve, sample TP1-1, ABMC 2019/063 17 Loxoconcha rhomboidea (Fischer, 1855), left valve, sample TP1-1, ABMC 2019/069 18 Loxoconcha ovulata (Costa, 1853), left valve, sample TP2-2, ABMC 2019/071 19 Cytherois uffenordei Ruggieri, 1974, left valve, sample TP1-2, ABMC 2019/064 20 Xestoleberis communis Müller, 1894, left valve, sample TP1-2, ABMC 2019/073 21 Xestoleberis dispar Müller, 1894, right valve, sample TP2-2, ABMC 2019/079 Scale bar $100 \mu \mathrm{m}$ 


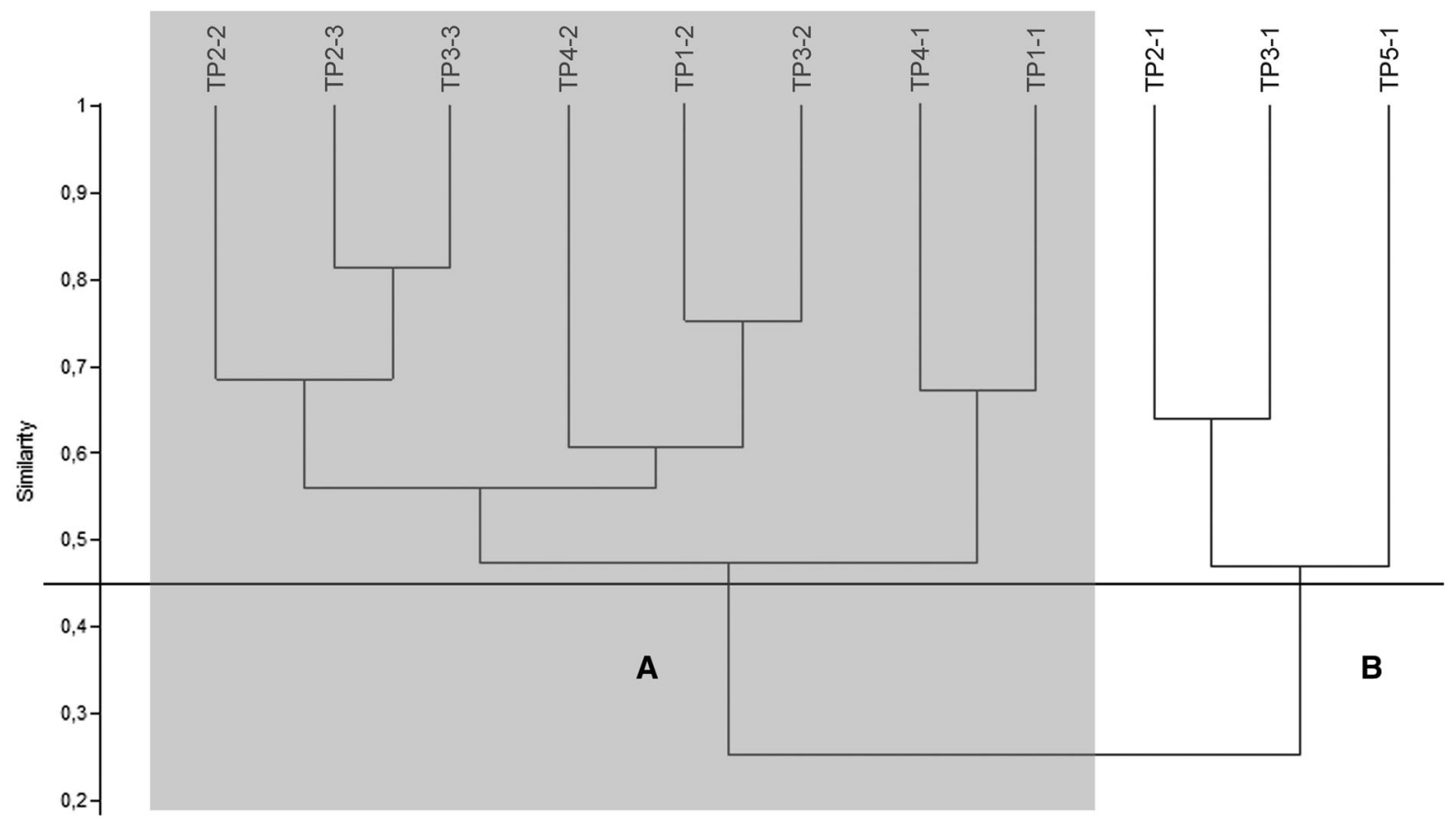

Fig. 4 Dendrogram based on cluster analysis of benthic foraminiferal and ostracod (MNI and TNV) abundance data (I)

the upper infralittoral zone. From a paleoecological point of view, the refining of the distribution range of paleobathymetric indicators is a primary objective. The paleodepth estimates of sedimentary successions, or levels, using benthic foraminifers and ostracods, may contribute to the reconstruction of the dynamics of volcanic areas (Aiello et al., 2007, 2012; Marturano et al., 2009; 2011a; 2011b; 2013; 2018; Di Vito et al., 2016; Isaia et al., 2019). The present results showed that high abundance values of the genera Paracytheridea and Urocythereis, and specifically of $P$. paulii and U. margaritifera, are characteristic of upper shoreface environments in waters shallower than $23 \mathrm{~m}$.

Pearson's correlation coefficient analysis of benthic foraminifers revealed that $T$. concinnus and taxa richness $(\mathrm{S})$ correlated with As; foraminiferal dominance with $\mathrm{Fe}$ and $\mathrm{Zn} ;$ Q. lata correlated with $\mathrm{Ni}, \mathrm{Pb}$, $\mathrm{Zn}$, TOC and anticorrelated with water depth.

The Pearson's correlation coefficient analysis of ostracods showed that $\mathrm{Cr}$ and $\mathrm{Cu}$ displayed high correlations with Carinocythereis whitei, Semicytherura incongruens (both MNI and TNV), L. rhomboidea (MNI), L. ovulata, and X. dispar and an inverse correlation with equitability $\mathrm{J}$ (TNV). Water depth correlated with $C$. turbida and taxa richness $\mathrm{S}$ (MNI and TNV), L. ovulata and Shannon Index H' (MNI), and anticorrelated with Paracytheridea paulii and $U$. margaritifera (MNI and TNV) and with Procytherideis retifera (MNI).

Total PAHs and total PD PAHs (Priority Dangerous PAHs) correlated with $P$. retifera $(\mathrm{MNI}), A$. convexa and $\mathrm{D}$ and showed an inverse correlation with $\mathrm{J}$ (TNV). Rare earth elements correlated with $A$. convexa and D (TNV).

Ni correlated with $P$. paulii, $P$. retifera, and $U$. margaritifera (MNI); As showed correlation with $L$. affinis (MNI and TNV), Cytherois uffenordei, Paracytheridea triquetra (MNI); Hg anticorrelated with $\mathrm{H}^{\prime}$ (TNV); TOC correlated with D(TNV).

\section{Discussion}

The study of shallow water samples of the Gulf of Pozzuoli allowed us to investigate the distribution of meiofaunal calcareous assemblages in an area subject 


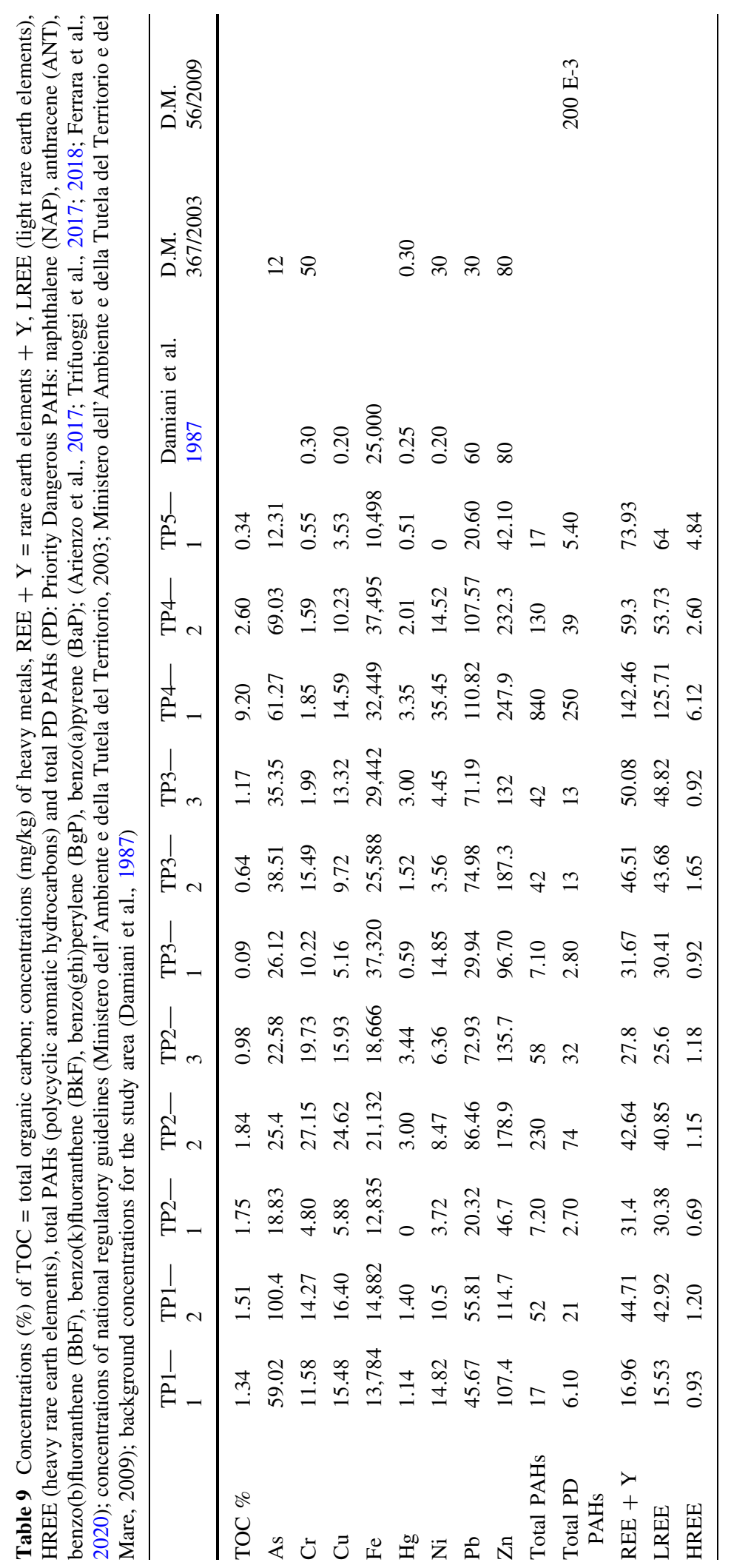




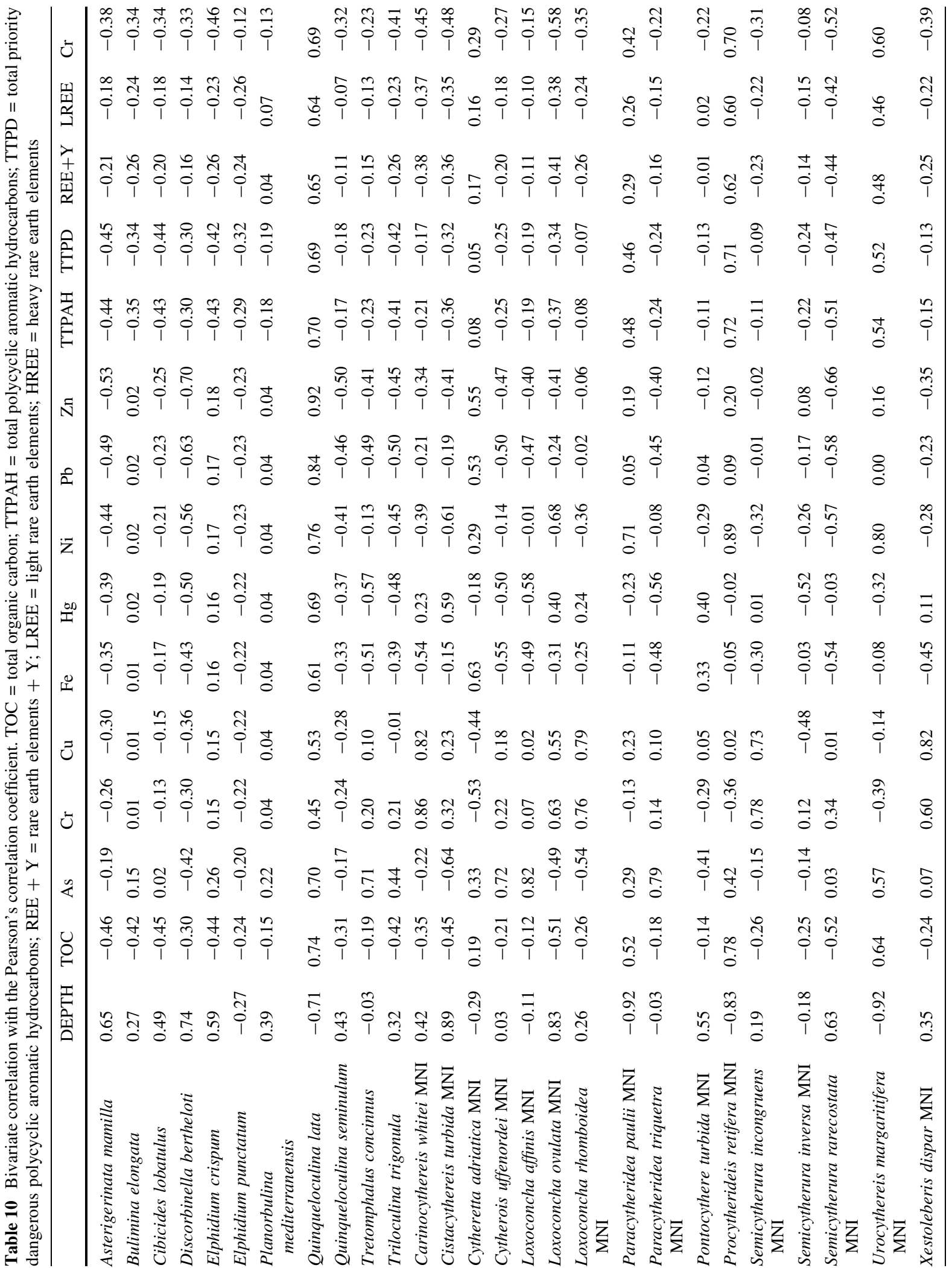




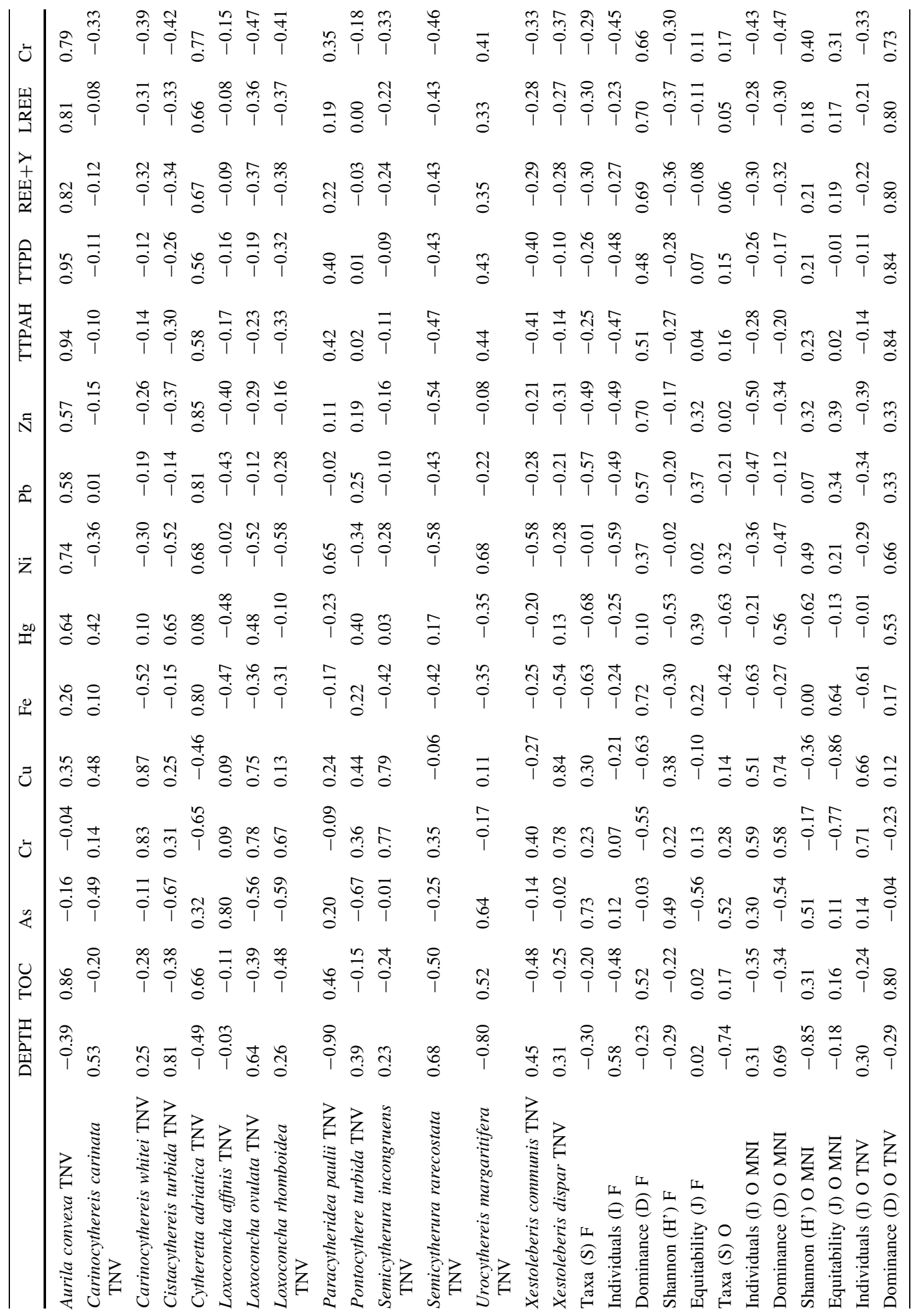


to long-term industrial and urban pollution. All the sediments were collected within the infralittoral zone where previous researches displayed high geoaccumulation levels, especially in the eastern part of the bay (Arienzo et al., 2017; Trifuoggi et al., 2017, 2018). Anthropogenic and natural environmental pressure may influence both the meiofaunal features (abundance, diversity indices, dominance) and the taxonomic composition of foraminiferal and ostracod assemblages. In the sediments of the Gulf of Pozzuoli, their diversity was strongly related to the grain size of the bottom sediments, being low in the coarse-grained samples and high in fine and very fine sands. The relationship between granulometry and meiofaunal diversity in shallow marine waters was investigated by several researchers, who identified indicative trends. Pokorný (1978) stated, as a general rule, that coarse sediments (e.g., oolites and clean sands), can hold only a limited number of ostracod species, whereas on pelitic bottoms and mud-mixed sands the diversity of the assemblages increases. A number of studies corroborated this relationship, showing high ostracod diversity in fine-grained sands and low diversity in coarser sediments (Hazel, 1975; Aiello et al., 2006), higher diversity on silts or mud-mixed sands, and lower in clean sands (Puri 1966, 1971) and negative correlation with granulometry in Quaternary sandy successions (Aiello et al., 2020). On the other hand, on muddy bottoms, ostracod diversity frequently diminishes (Benson \& Maddocks, 1964; Hong, 2016); consequently, it was suggested that the relationship between "ostracod diversity and particle size fractionation is not unimodal but rather hump shape" (Hong, 2016).

A similar trend was observed concerning benthic foraminifers. Investigations on assemblages collected on muddy bottom recorded low diversity, increasing in sandy sediments (Diz et al., 2004; Debenay et al., 2005); in large-grain sands and coarser bottom sediments a decrease was observed (Samir \& El-Din, 2001; Temelkov, 2008; Delaine et al., 2015). It has to be noted that some studies reported apparently contradictory results, showing, for example, high foraminiferal diversity in sheltered areas with finegrained sediments and high ostracod diversity in more exposed coarser-grained sediments (Morley \& Hayward, 2014).

The characteristic of the assemblages occurring in the study samples supported the link between 
granulometry and calcareous meiofaunal diversity. Coarse-grained sediments were present in the samples TP3-1 (medium sand), TP2-1 (coarse sand), and TP5-1 (very fine gravel), where the ostracod dominance is high, whereas abundance and diversity are low; foraminiferal taxa richness and abundance are low. In the infralittoral zone of the bay, muddy sediments were virtually absent, and Pokorný's statement was confirmed by higher diversity and lower dominance displayed by ostracod, and, to a lesser extent, by benthic foraminiferal assemblages in fine and very fine sandy samples.

Chemical analyses revealed lower concentrations of pollutants in coarse-grained samples. Arsenic, copper, mercury, lead, zinc, total polycyclic aromatic hydrocarbons (pahs; in particular anthracene, benzo(a)anthracene, benzo(b)fluoranthene, and chrysene) and priority dangerous pahs were significantly higher in fine and very fine sands. The recognized inverse relationship between grain size and anthropogenic chemical contaminants (Horowitz, 1985, 1991; Herut \& Sandler, 2006) and the abovementioned link between meiofaunal remains and granulometry, could erroneously suggest the preference of ostracod and benthic foraminiferal assemblages for polluted bottom sediments. Consequently, to achieve reliable results, we considered separately the fine sandy samples and the coarser-grained sediments.

Calcareous meiofaunal assemblages exhibit different responses to anthropogenic inputs, including the decrease in diversity and increase in the abundance of tolerant taxa or morphotypes typical of polluted waters (Frontalini \& Coccioni, 2008, 2011; Yasuhara et al., 2012; Wilkinson et al., 2014). As regards the presence of pollutants in the bottom sediments, researchers assumed that the geochemical nature of the substrate exerts only a modest influence on benthic foraminiferal and ostracod assemblages (Albani et al., 1998; Eagar, 1999; Irizuki et al., 2015); conversely, some investigations suggested negative effects (Schornikov, 2000; Mostafawi, 2001; Martins et al., 2015) or displayed controversial results (Coccioni, 2000; Debenay \& Fernandez, 2009; Choi \& An, 2012).

Our point of view is that neither the contaminants accumulated in the bottom sediments nor the dead assemblages are representative of the ecological conditions at the time of sampling. Instead, they are indicative of the environmental history of the bay
Table 11 Comparative table of diversity/dominance indices mean values of benthic foraminiferal and ostracod infralittoral assemblages of northwestern Campanian coastal areas (only fine and very fine sands); MDP = Monte di Procida (Mangoni et al., 2016), FD = Litorale Falerno Domitio (Balassone et al., 2016), GPI = infralittoral assemblages of the Gulf of Pozzuoli (this paper)

\begin{tabular}{llll}
\hline & MDP & FD & GPI \\
\hline Foraminifera & & & \\
Taxa (S) & 51 & 36 & 61 \\
Individuals (I) & 7376 & 12,356 & 51,540 \\
Dominance (D) & 0.08 & 0.12 & 0.05 \\
Shannon (H') & 3.25 & 2.73 & 3.49 \\
Equitability (J) & 0.83 & 0.77 & 0.85 \\
Ostracoda MNI & & & \\
Taxa (S) & 35 & 21 & 48 \\
Individuals (I) & 268 & 865 & 2066 \\
Dominance (D) & 0.09 & 0.17 & 0.05 \\
Shannon (H') & 2.93 & 2.25 & 3.35 \\
Equitability (J) & 0.84 & 0.77 & 0.87 \\
Ostracoda TNV & & & \\
Individuals (I) & 822 & 3447 & 7781 \\
Dominance (D) & 0.13 & 0.18 & 0.07 \\
Shannon (H') & 2.64 & 2.17 & 3.10 \\
Equitability (J) & 0.76 & 0.74 & 0.81 \\
\hline
\end{tabular}

during the last years or decades. On the base of the present data, it is hypothesized that the continued anthropogenic disturbance, primarily due to industrial wastes, had not resulted in a decrease in ostracod and benthic foraminiferal diversity and had its effect by changing the taxonomic composition of the assemblages. In Table 11, the mean values of diversity indices of the infralittoral assemblages of Monte di Procida (Mangoni et al., 2016) and Falerno-Domitio (Balassone et al., 2016) were reported. Both ostracod and benthic foraminiferal assemblages of the Gulf of Pozzuoli showed higher diversity and lower dominance in comparison with the nearby areas. The expected response to contaminant input was the decrease in meiofaunal diversity, nonetheless, some investigations on benthic foraminifers reported inverse trends (Debenay \& Fernandez, 2009 and Li et al., 2015, in metal-contaminated waters) and highly diversified assemblages in polluted waters (Romano et al., 2009 and Choi \& An, 2012, in metal-contaminated waters; Armynot du Châtelet et al., 2011, in metal-contaminated, rich organic carbon waters). 
Barras et al. (2014) suggested that in oligotrophic environments the diversity indices are not appropriate to describe water quality. Moreover, the common presence of miliolids implies coastal waters supersaturated in calcium carbonate (Aiello et al., 2018, and references therein) where the presence of industrial wastes did not result in a $\mathrm{pH}$ lowering.

Reports of high-diversity ostracod assemblages in stressed environments are very rare (Amato et al., 2019; Aiello et al., 2020) which hampers to perform a proper comparison with the present study.

\section{Conclusions}

A quantitative study of benthic foraminiferal and ostracod assemblages, integrated with chemical and sedimentological parameters, was carried out along the coast of the Gulf of Pozzuoli. A total of 11 samples were collected within the infralittoral zone, to investigate the relationship between meiofaunal calcareous remains and pollution indicators preserved in the shallow marine bottom sediments of the bay. Assemblages were characterized by species typical of infralittoral Mediterranean environments such as the benthic foraminifers A. aberdoveyensis, B. granulata, and $C$. lobatulus, and the ostracods $U$. margaritifera and P. turbida. The genera Elphidium and Quinqueloculina (Foraminifera), and Semicytherura and Xestoleberis (Ostracoda) were highly diversified.

Despite the continued anthropogenic disturbance, testified by high geoaccumulation levels, the shallow bottom sediments of the Gulf of Pozzuoli yielded high-diversity, low-dominance assemblages. It was here hypothesized that the oligotrophic, well-oxygenated, and supersaturated in $\mathrm{CaCO}_{3}$ shallow Tyrrhenian waters may promote "complex trophic relationship" and "full exploitation of ecological niches" as stated by Holbourn et al. (2013) in their investigations on foraminiferal deep-water assemblages. The diversity was linked to the grain size of the bottom sediments, being higher on fine and very fine sands, and lower on coarser sediments.

On the other hand, the comparison with the assemblages collected in 1961 in the Gulf of Pozzuoli and the Gulf of Naples showed an increase in the abundance of taxa that are suggested to tolerate to geochemical pollution ( $Q$. seminulum, B. elongata, Xestoleberis, Loxoconcha, S. rarecostata). Statistical analysis confirmed the tolerance of $Q$. lata to a high level of heavy metals contaminants and the preference of $U$. margaritifera and $P$. paulii for the shallow part of the infralittoral zone.

Acknowledgements The authors thank Roberto de' Gennaro (DiSTAR, Università di Napoli Federico II) who took the SEM micrographs. We also acknowledge the kind collaboration of the Lega Navale di Pozzuoli, Italy, for providing us the motor vessel Antilia, the skipper Raffaele Donadio, the Captaincy of Port of Pozzuoli and Lieutenant Commander Angelo Benedetto Gonnella for assistance to the operations at sea. Finally, we are grateful to the University of Naples Federico II for supporting our research in the APC for open access.

Author contributions Giuseppe Aiello involved in conceptualization, writing-original draft preparation, investigation; Diana Barra took part in conceptualization, investigation, writing-review \& editing; Roberta Parisi participated in formal analysis, investigation; Carlo Donadio took part in data curation, investigation; Michele Arienzo involved in formal analysis, investigation, resources; Luciano Ferrara took part in formal analysis, investigation, resources; Maria Toscanesi involved in investigation, resources; Marco Trifuoggi participated in investigation, resources.

Funding Open access funding provided by Università degli Studi di Napoli Federico II within the CRUI-CARE Agreement. No funding was received for conducting this study.

Data availability All data generated or analyzed during this study are included in this published article [and its supplementary information files].

\section{Declaration}

Conflicts of interest The authors have no financial or proprietary interests in any material discussed in this article.

Open Access This article is licensed under a Creative Commons Attribution 4.0 International License, which permits use, sharing, adaptation, distribution and reproduction in any medium or format, as long as you give appropriate credit to the original author(s) and the source, provide a link to the Creative Commons licence, and indicate if changes were made. The images or other third party material in this article are included in the article's Creative Commons licence, unless indicated otherwise in a credit line to the material. If material is not included in the article's Creative Commons licence and your intended use is not permitted by statutory regulation or exceeds the permitted use, you will need to obtain permission directly from the copyright holder. To view a copy of this licence, visit http://creativecommons.org/licenses/by/4.0/. 


\section{Appendix 1}

Benthic foraminiferal and ostracod list of species.

\section{List of benthic foraminiferal species}

Adelosina elegans (Williamson, 1858)

Adelosina longirostra (d'Orbigny, 1826).

Adelosina mediterranensis (Le Calvez \& Le Calvez, 1958).

Adelosina pulchella d'Orbigny, 1826.

Affinetrina planciana (d'Orbigny, 1839).

Ammodiscus planorbis Höglund, 1947.

Ammonia aberdoveyensis Haynes, 1973 lobate form.

Ammonia aberdoveyensis Haynes, 1973 rounded form.

Ammonia beccarii (Linnaeus, 1758).

Amphicoryna scalaris (Batsch, 1791).

Angulogerina angulosa (Williamson, 1858).

Asterigerinata adriatica Haake, 1977.

Asterigerinata mamilla (Williamsom, 1858).

Asterigerinata mariae Sgarrella, 1990.

Astrononion stelligerum (d'Orbigny, 1839).

Bolivina catanensis Seguenza, 1862.

Bolivina lowmani Phleger \& Parker, 1951.

Bolivina pseudoplicata Heron-Allen \& Earland, 1930.

Bolivina variabilis (Williamson, 1858).

Bolivina sp.

Brizalina spathulata (Williamson, 1858).

Brizalina striatula (Cushman, 1922).

Buccella granulata (Di Napoli Alliata, 1952).

Bulimina aculeata d'Orbigny, 1826.

Bulimina elongata d'Orbigny, 1846.

Cassidulina carinata Silvestri, 1896.

Cibicides lobatulus (Walker \& Jacob, 1798).

Cibicides refulgens Montfort, 1808.

Cibicidoides pachyderma (Rzehak, 1886).

Cibicidoides variabilis (d'Orbigny, 1826).

Conorbella imperatoria (d'Orbigny, 1846).

Cornuspira involvens (Reuss, 1850).

Cycloforina contorta (d'Orbigny, 1846).

Cycloforina rugosa (d'Orbigny, 1826).

Cycloforina tenuicollis (Wiesner, 1923).

Cycloforina villafranca (Le Calvez \& Le Calvez, 1958).

Discorbinella bertheloti (d'Orbigny, 1839).
Discorbis torrei Bermúdez, 1935.

Eggerelloides scaber (Williamson, 1858).

Eilohedra vitrea (Parker, 1953).

Elphidium articulatum (d'Orbigny, 1839).

Elphidium complanatum (d'Orbigny, 1839).

Elphidium crispum (Linnaeus, 1758).

Elphidium granosum (d'Orbigny, 1846).

Elphidium incertum (Williamson, 1858).

Elphidium macellum (Fichtel \& Moll, 1798).

Elphidium maioricense Colom, 1942.

Elphidium poeyanum (d'Orbigny, 1839) DS form.

Elphidium poeyanum (d'Orbigny, 1839) FS form.

Elphidium pulvereum Todd, 1958.

Elphidium punctatum (Terquem, 1878).

Favulina hexagona (Williamson, 1848).

Flintinoides labiosa (d'Orbigny, 1839).

Fursenkoina acuta (d'Orbigny, 1846).

Gavelinopsis praegeri (Heron-Allen \& Earland, 1913).

Glabratella erecta (Sidebottom, 1908).

Glabratella hexacamerata Seiglie \& Bermúdez, 1965.

Globobulimina sp. 1

Globocassidulina subglobosa (Brady, 1881).

Globulina gibba (d'Orbigny, 1826).

Guttulina sp. 1

Gyroidina neosoldanii Brotzen, 1936.

Gyroidina umbonata (Silvestri, 1898).

Haynesina depressula (Walker \& Jacob, 1798).

Haynesina germanica (Ehrenberg, 1840).

Lachlanella undulata (d'Orbigny, 1852).

Lagena semistriata Wiliamson, 1848.

Lenticulina cultrata (Montfort, 1808).

Lenticulina gibba (d'Orbigny, 1839).

Lenticulina rotulata (Lamarck, 1804).

Massilina secans (d'Orbigny, 1826).

Melonis affinis (Reuss, 1851).

Miliolidae.

Miliolinella elongata Kruit, 1955.

Miliolinella cf. hybrida (Terquem, 1878).

Miliolinella semicostata (Wiesner, 1923).

Miliolinella subrotunda (Montagu, 1803).

Miliolinella webbiana (d'Orbigny, 1839).

Miniacina miniacea (Pallas, 1766).

Neoconorbina terquemi (Rzehak, 1888).

Nonionella turgida (Williamson, 1858).

Nubecularia lucifuga Defrance, 1825.

Palliolatella fasciata (Egger, 1857).

Parrina bradyi (Millett, 1898). 
Peneroplis pertusus (Forskål, 1775).

Peneroplis planatus (Fichtel \& Moll, 1798).

Planoglabratella opercularis (d'Orbigny, 1846).

Planorbulina mediterranensis d'Orbigny, 1826.

Quinqueloculina agglutinans d'Orbigny, 1839.

Quinqueloculina annectens (Schlumberger, 1893).

Quinqueloculina berthelotiana d'Orbigny, 1839.

Quinqueloculina bosciana d'Orbigny, 1839.

Quinqueloculina bradyana Cushman, 1917.

Quinqueloculina disparilis d'Orbigny, 1826.

Quinqueloculina irregularis d'Orbigny, 1826.

Quinqueloculina jugosa Cushman, 1944.

Quinqueloculina laevigata d'Orbigny, 1839.

Quinqueloculina lata Terquem, 1876.

Quinqueloculina limbata d'Orbigny, 1826.

Quinqueloculina parvula Schlumberger, 1894.

Quinqueloculina poeyana d'Orbigny, 1839.

Quinqueloculina pygmaea Reuss, 1850.

Quinqueloculina seminulum (Linnaeus, 1758).

Quinqueloculina stalkeri Loeblich \& Tappan, 1953.

Quinqueloculina stelligera Schlumberger, 1893.

Quinqueloculina ungeriana d'Orbigny, 1846.

Quinqueloculina vulgaris d'Orbigny, 1826.

Quinqueloculina sp.

Rectuvigerina phlegeri Le Calvez, 1959.

Reophax fusiformis (Williamson, 1858).

Reussella spinulosa (Reuss, 1850).

Rosalina floridana (Cushman, 1922).

Rosalina macropora (Hofker, 1951).

Rosalina obtusa d'Orbigny, 1846.

Rotorbis auberii (d'Orbigny, 1839).

Sahulia conica (d'Orbigny, 1839).

Sigmoilina costata Schlumberger, 1893.

Sigmoilina grata (Terquem, 1878).

Sigmoilinita distorta (Phleger \& Parker, 1951).

Siphonaperta aspera (d'Orbigny, 1826).

Siphonina reticulata (Cžjžek, 1884).

Sorites orbicularis (Forskål, 1775).

Spirillina vivipara Ehrenberg, 1843.

Spiroloculina depressa d'Orbigny, 1826.

Spiroloculina excavata d'Orbigny, 1846.

Spiroloculina ornata d'Orbigny, 1839.

Spiroloculina tricarinata d'Orbigny, 1852.

Spiroplectinella wrighti (Silvestri, 1903).

Stainforthia complanata (Egger, 1893).

Stomatorbina concentrica (Parker \& Jones, 1864).

Textularia aciculata d'Orbigny, 1826.

Textularia agglutinans d'Orbigny, 1839.
Textularia calva Lalicker, 1940.

Textularia pala Cžjžek, 1848.

Tretomphalus concinnus (Brady, 1884).

Triloculina eburnea d'Orbigny, 1839.

Triloculina plicata Terquem, 1878.

Triloculina schreiberiana d'Orbigny, 1839.

Triloculina trigonula (Lamarck, 1804).

Trochammina inflata (Montagu, 1808).

Uvigerina mediterranea Hofker, 1932.

Valvulineria complanata (d'Orbigny, 1846).

Vertebralina striata d'Orbigny, 1826.

Wiesnerella auriculata (Egger, 1895).

\section{List of ostracod species}

Aglaiocypris complanata (Brady \& Robertson, 1869).

Argilloecia minor Müller, 1894

Aurila convexa (Baird, 1850).

Aurila prasina Barbeito-Gonzalez, 1971.

Aurila speyeri (Brady, 1858).

Callistocythere crispata (Brady, 1868).

Callistocythere flavidofusca (Ruggieri, 1950).

Callistocythere lobiancoi (Müller, 1894).

Callistocythere aff. C. protracta Ruggieri \& D'Arpa, 1993.

Carinocythereis carinata (Roemer, 1838).

Carinocythereis whitei (Baird, 1850).

Cistacythereis turbida (Müller, 1894).

Costa batei (Brady, 1866).

Costa edwardsii (Roemer, 1838).

Cyprideis torosa (Jones, 1850).

Cytheretta adriatica Ruggieri, 1952.

Cytheretta subradiosa (Roemer, 1838).

Cytheridea neapolitana Kollmann, 1960.

Cytherois frequens Müller, 1894

Cytherois joachinoi Barra, 1992.

Cytherois aff. C. niger Schornikov, 1965.

Cytherois aff. C. pontica Marinov, 1966.

Cytherois triangularis Bonaduce, Masoli, Minichelli \& Pugliese, 1979.

Cytherois uffenordei Ruggieri, 1974.

Cytherois sp. 1

Cytheroma variabilis Müller, 1894

Cytheropteron latum Müller, 1894

"Elofsonia" minima (Bonaduce, Ciampo \& Masoli, 1976).

Eucytherura gibbera Müller, 1894

Hemicytherura defiorei Ruggieri, 1953. 
Hemicytherura videns (Müller, 1894).

Heterocythereis voraginosa Athersuch, 1979.

Leptocythere levis (Müller, 1894).

Leptocythere macella Ruggieri, 1975.

Leptocythere ramosa (Rome, 1942).

Loxocauda decipiens (Müller, 1894).

Loxoconcha affinis (Brady, 1866).

Loxoconcha concentrica Bonaduce, Ciampo \& Masoli, 1976.

Loxoconcha ovulata (Costa, 1853).

Loxoconcha rhomboidea (Fischer, 1855).

Loxoconcha stellifera Müller, 1894

Macrocyprina succinea (Müller, 1894).

Microcythere depressa Müller, 1894

Microcythere hians Müller, 1894

Microcythere ? rara Müller, 1894

Microcythere vitrea Bonaduce, Ciampo \& Masoli, 1976.

Microcytherura fulva (Brady \& Robertson, 1874).

Microcytherura nigrescens Müller, 1894

"Microcytherura" sp. 1

Microxestoleberis nana Müller, 1894

Microxestoleberis sp.

Neocytherideis subulata (Brady, 1868).

Neonesidea mediterranea (Müller, 1894).

Palmoconcha subrugosa (Ruggieri, 1977).

Palmoconcha turbida (Müller, 1894).

Paracytheridea paulii Dubowsky, 1939.

Paracytheridea triquetra (Reuss, 1850).

Paracytherois agigensis Caraion, 1963.

Paracytherois flexuosa (Brady, 1867).

Paradoxostoma atrum Müller, 1894

Paradoxostoma acuminatum Müller, 1894

Paradoxostoma angustum Müller, 1894

Paradoxostoma caecum Müller, 1894

Paradoxostoma parallelum Müller, 1894

Paradoxostoma aff. P. rotundatum Müller, 1894

Paradoxostoma simile Müller, 1894

Paradoxostoma triste Müller, 1894

Phlyctocythere pellucida (Müller, 1894).

Polycope reticulata Müller, 1894

Pontocypris acuminata (Müller, 1894).

Pontocypris frequens (Müller, 1894).

Pontocypris obtusa (Müller, 1894).

Pontocypris pellucida Müller, 1894

Pontocypris aff. P. pellucida Müller, 1894

Pontocythere turbida (Müller, 1894).

Procytherideis retifera Ruggieri, 1978.
Procytherideis subspiralis (Brady, Crosskey \& Robertson, 1874).

Propontocypris intermedia (Brady, 1868).

Propontocypris rara (Müller, 1894).

Propontocypris subfusca (Müller, 1894).

Propontocypris succinea (Müller, 1894).

Propontocypris sp. 1

Pseudocytherura strangulata Ruggieri, 1991.

Pseudopsammocythere reniformis (Brady, 1868).

Pterygocythereis jonesii (Baird, 1850).

Sagmatocythere napoliana (Puri, 1963).

Sagmatocythere versicolor (Müller, 1894).

Sahnicythere retroflexa (Klie, 1936).

Sclerochilus? aequus Müller, 1894

Sclerochilus gewemuelleri Dubowsky, 1939.

Sclerochilus levis Müller, 1894

Semicytherura acuta (Müller, 1912).

Semicytherura acuticostata (Sars, 1866).

Semicytherura alifera Ruggieri, 1959.

Semicytherura costata (Müller, 1894).

Semicytherura dispar (Müller, 1894).

Semicytherura incongruens (Müller, 1894).

Semicytherura inversa (Seguenza, 1880).

Semicytherura paradoxa (Müller, 1894).

Semicytherura punctata (Müller, 1894).

Semicytherura quadridentata (Hartmann, 1953)

Semicytherura rarecostata Bonaduce, Ciampo \& Masoli, 1976.

Semicytherura reticulata (Müller, 1894).

Semicytherura robusta Bonaduce, Ciampo \& Masoli, 1976.

Semicytherura ruggierii (Pucci, 1955).

Semicytherura simplex (Brady \& Norman, 1889).

Semicytherura aff. S. slavonica Krstić, 1983.

Semicytherura sulcata (Müller, 1894).

Semicytherura tergestina Masoli, 1968.

Tenedocythere prava (Baird, 1850).

Triebelina raripila (Müller, 1894).

Tuberoloxococncha tuberosa (Hartmann, 1954).

Urocythereis ilariae Aiello, Barra \& Parisi, 2016

Urocythereis margaritifera (Müller, 1894).

Urocythereis schulzi (Hartmann, 1958).

Xestoleberis communis Müller, 1894

Xestoleberis decipiens Müller, 1894

Xestoleberis dispar Müller, 1894

Xestoleberis aff. X. labiata Brady \& Robertson, 1874.

Xestoleberis margaritopsis Rome, 1942.

Xestoleberis pellucida Müller, 1894 
Xestoleberis aff. X. pellucida Müller, 1894

Xestoleberis cf. X. perminima Neviani, 1928.

Xestoleberis aff. X. perula Athersuch, 1978.

Xestoleberis plana Müller, 1894

Xestoleberis rara Müller, 1894

Xestoleberis sp. 1

\section{References}

Aiello G, Barra D (2010) Crustacea, Ostracoda. Biol Mar Mediterr 17:401-419. https://doi.org/10.1093/oso/ 9780199233267.003.0025

Aiello G, Barra D, Coppa MG, Valente A, Zeni F (2006) Recent infralittoral foraminiferida and ostracoda from the porto Cesareo Lagoon (Ionian Sea, Mediterranean). Boll Soc Paleontol Ital 45:1-14

Aiello G, Barra D, De Pippo T, Donadio C, Petrosino C (2007) Geomorphological evolution of Phlegrean volcanic islands near Naples, southern Italy. Zeitschrift Für Geomorphol NF 51(2):165-190. https://doi.org/10.1127/0372-8854/ 2007/0051-0165

Aiello G, Barra D, De Pippo T, Donadio C (2012) Pleistocene foraminiferida and ostracoda from the island of Procida (Bay of Naples, Italy). Boll Soc Paleontol Ital 51(1):49-62. https://doi.org/10.4435/BSPI.2012.06

Aiello G, Barra D, Parisi R (2016) Intra- and interspecific shell variability of the genus Urocythereis Ruggieri, 1950 (Ostracoda: Hemicytheridae) in the La Strea Bay (Ionian Sea, Italy). Eur J Taxon 193:1-35. https://doi.org/10.5852/ejt. 2016.193

Aiello G, Barra D, Parisi R, Isaia R, Marturano A (2018) Holocene benthic foraminiferal and ostracod assemblages in a paleo-hydrothermal vent system of Campi Flegrei (Campania, South Italy). Palaeontol Electron 21.3.41A 1-71. https://doi.org/10.26879/835

Aiello G, Amato V, Barra D, Caporaso L, Caruso T, Giaccio B, Parisi R, Rossi A (2020) Late Quaternary benthic foraminiferal and ostracod response to palaeoenvironmental changes in a Mediterranean coastal area, Port of Salerno. Tyrrhenian Sea Reg Stud Mar Sci 40:101498. https://doi. org/10.1016/j.rsma.2020.101498

Aiello G, Amato V, Aucelli PPC, Barra D, Corrado G, Di Leo P, Di Lorenzo H, Jicha B, Pappone G, Parisi R, Petrosino P, Russo Ermolli E, Schiattarella M (2021) Multiproxy study of cores from the Garigliano Plain: an insight into the late quaternary coastal evolution of Central-Southern Italy. Palaeogeogr Palaeoclim Palaeoecol 567:110298. https:// doi.org/10.1016/j.palaeo.2021.110298

Albani AD, Favero VM, Serandrei Barbero R (1998) Distribution of sediment and benthic foraminifera in the Gulf of Venice. Italy Estuar Coast Shelf Sci 46(2):251-265. https:// doi.org/10.1006/ecss.1997.0261

Alve E (1991) Foraminifera, climatic change, and pollution: a study of late Holocene sediments in Drammensfiord, southeast Norway. Holocene 1(3):243-261. https://doi.org/ $10.1177 / 095968369100100306$
Alve E, Lepland A, Magnusson J, Backer-Owe K (2009) Monitoring strategies for re-establishment of ecological reference conditions: Possibilities and limitations. Mar Pollut Bull 59(8-12):297-310. https://doi.org/10.1016/j. marpolbul.2009.08.011

Amato V, Aiello G, Barra D, Caporaso L, Caruso T, Giaccio B, Parisi R, Rossi A (2019) Holocene paleogeographic evolution of an ancient port city of the central Mediterranean area: natural and anthropogenic modifications from Salerno city, southern Italy. Geoarchaeology 35(3):366-383. https://doi.org/10.1002/gea.21774

Arienzo M, Donadio C, Mangoni O, Bolinesi F, Stanislao C, Trifuoggi M, Toscanesi M, Di Natale G, Ferrara L (2017) Characterization and source apportionment of polycyclic aromatic hydrocarbons (pahs) in the sediments of gulf of Pozzuoli (Campania, Italy). Mar Pollut Bull 124(1):480-487. https://doi.org/10.1016/j.marpolbul. 2017.07.006

Arienzo M, Bolinesi F, Aiello G, Barra D, Donadio C, Stanislao C, Ferrara L, Mangoni O, Toscanesi M, Tiara A, Trifuoggi M (2020) The environmental assessment of an estuarine transitional environment. Southern Italy J Mar Sci Eng $8: 628$

Armynot du Châtelet EA, Gebhardt K, Langer MR (2011) Coastal pollution monitoring: foraminifera as tracers of environmental perturbation in the port of Boulogne-surMer (Northern France). Neues Jahrb Geol Palaontol Abh 262(1):91-116. https://doi.org/10.1127/0077-7749/2011/ 0187

Balassone G, Aiello G, Barra D, Cappelletti P, De Bonis A, Donadio C, Guida M, Melluso L, Morra V, Parisi R, Pennetta M, Siciliano A (2016) Effects of anthropogenic activities in a Mediterranean coastland: the case study of the falerno-domitio littoral in Campania, Tyrrhenian Sea (southern Italy). Mar Pollut Bull 112(1-2):271-290. https://doi.org/10.1016/j.marpolbul.2016.08.004

Barras C, Jorissen FJ, Labrune C, Andral B, Boissery P (2014) Live benthic foraminiferal faunas from the French Mediterranean Coast: towards a new biotic index of environmental quality. Ecol Indic 36:719-743. https://doi.org/ 10.1016/j.ecolind.2013.09.028

Benson RH, Maddock RF (1964) Recent ostracodes of Knysna Estuary, Cape Province, Union of South Africa. Univ Kansas Paleontol Contrib, Arthropoda 5:1-39

Bergin F, Kucuksezgin F, Uluturhan E, Barut IF, Meric E, Avsar N, Nazik A (2006) The response of benthic foraminifera and ostracoda to heavy metal pollution in Gulf of Izmir (Eastern Aegean Sea). Estuar Coast Shelf Sci 66(3-4):368-386. https://doi.org/10.1016/j.ecss.2005.09. 013

Bolinesi F, Arienzo M, Donadio C, Ferrara L, Passarelli A, Saggiomo M, Saggiomo V, Stanislao C, Trifuoggi M, Mangoni O (2020) Spatial and temporal variation of phytoplankton community structure in a coastal marine system subjected to human pressure. Reg Stud Mar Sci 35:101198. https://doi.org/10.1016/j.rsma.2020.101198

Choi JU, An S (2012) High benthic foraminiferal diversity in polluted Busan North Port (Korea). J Foraminiferal Res 42(4):327-339. https://doi.org/10.2113/gsjfr.42.4.327

Coccioni R (2000) Benthic foraminifera as bioindicators of heavy metal pollution. In: Martin RE (ed) Environmental 
Micropaleontology: The Application of Microfossils to Environmental Geology Kluwer Academic/Plenum Publishers, . Boston, New York. https://doi.org/10.1007/978-14615-4167-7_4

Cronin TM, Vann CD (2003) The sedimentary record of climatic and anthropogenic influence on the patuxent estuary and chesapeake bay ecosystems. Estuaries 26(2):196-209. https://doi.org/10.1007/bf02695962

Damiani V, Baudo R, De Rosa S, De Simone R, Ferretti O, Izzo G, Serena F (1987) A case study: bay of Pozzuoli (Gulf of Naples, Italy). Hydrobiol 149:201-211. https://doi.org/10. 1007/978-94-009-4053-6_21

De Maio A, Moretti M, Sansone E, Spezie G, Vultaggio M (1985) Outline of marine currents in the Bay of Naples and some considerations on pollutant transport. Il Nuovo Cimento 8(6):955-969. https://doi.org/10.1007/ BF02558022

De Pippo T, Donadio C, Pennetta M, Petrosino C, Terlizzi F, Valente A (2008) Coastal hazard assessment and mapping in Northern Campania. Italy Geomorphol 97(3-4):451-466. https://doi.org/10.1016/j.geomorph. 2007.08.015

de Ruggiero P, Napolitano E, Iacono R, Pierini S (2016) A highresolution modelling study along the Campania coastal system, with a special focus on the Gulf of Naples. Continental Shelf Res 122:85-101. https://doi.org/10.1016/j. csr.2016.03.026

Debenay JP, Fernandez JM (2009) Benthic foraminifera records of complex anthropogenic environmental changes combined with geochemical data in a tropical bay of New Caledonia (SW Pacific). Mar Pollut Bull 59(8-12):311-322. https://doi.org/10.1016/j.marpolbul. 2009.09.014

Debenay J-P, Millet B, Angelidis MO (2005) Relationships between foraminiferal assemblages and hydrodynamics in the Gulf of Kalloni, Greece. J Foraminiferal Res 35:327-343. https://doi.org/10.2113/35.4.327

Debenay JP, Della Patrona L, Herbland A, Goguenheim H (2009) The impact of easily oxidized material (EOM) on the meiobenthos: foraminifera abnormalities in shrimp ponds of New Caledonia; implications for environment and paleoenvironment survey. Mar Pollut Bull 59(8-12):323-335. https://doi.org/10.1016/j.marpolbul. 2009.08.012

Delaine M, Armynot du Châtelet E, Bout-Roumazeilles V, Goubert E, Le Cadre V, Recourt P, Trentesaux A, Arthuis R (2015) Multiproxy approach for Holocene paleoenvironmental reconstructions from microorganisms (testate amoebae and foraminifera) and sediment analyses: the infilling of the Loire Valley in Nantes (France). Holocene 25:407-420. https://doi.org/10.1177/0959683614561883

Di Vito MA, Acocella V, Aiello G, Barra D, Battaglia M, Carandente A, Del Gaudio C, de Vita S, Ricciardi GP, Ricco C, Scandone R, Terrasi F (2016) Magma transfer at Campi Flegrei caldera (Italy) before the last $1538 \mathrm{AD}$ eruption. Sci Rep 6:32245. https://doi.org/10.1038/ srep32245

Diz P, Francés G, Costas S, Souto C, Alejo I (2004) Distribution of benthic foraminifera in coarse sediments, Ría de Vigo. NW Iberian Margin J Foraminiferal Res 34(4):258-275. https://doi.org/10.2113/34.4.258
Eagar SH (1999) Distribution of Ostracoda around a coastal sewer outfall: a case study from Wellington, New Zealand. J R Soc N Z 29(3):257-264. https://doi.org/10.1080/ 03014223.1999.9517596

Elshanawany R, Ibrahim MI, Milker Y, Schmiedl G, Badr N, Kholeif SE, Zonneveld KA (2011) Anthropogenic impact on benthic foraminifera, Abu-Qir Bay, Alexandria. Egypt J Foraminiferal Res 41(4):326-348. https://doi.org/10.2113/ gsjfr.41.4.326

Elshanawany R, Ibrahim MI, Frihy O, Abodia M (2018) Foraminiferal evidence of anthropogenic pollution along the Nile Delta coast. Environ Earth Sci 77:444. https://doi.org/ 10.1007/s12665-018-7643-8

Ferrara L, Trifuoggi M, Toscanesi M, Donadio C, Barra D, Aiello G, Arienzo M (2020) Source identification and ecorisk assessment of polycyclic aromatic hydrocarbons in the sediments of seawaters facing the former steel plant ILVA, Naples. Italy Reg Stud Mar Sci 35:101097. https://doi.org/ 10.1016/j.rsma.2020.101097

Folk RL, Ward WC (1957) Brazos River bar: a study in the significance of grain size parameters. J Sediment Petrol 27(1):3-26. https://doi.org/10.1306/74D70646-2B2111D7-8648000102C1865D

Frontalini F, Coccioni R (2008) Benthic foraminifera for heavy metal pollution monitoring: a case study from the central Adriatic Sea coast of Italy. Estuar Coast Shelf Sci 76(2):404-417. https://doi.org/10.1016/j.ecss.2007.07.024

Frontalini F, Coccioni R (2011) Benthic foraminifera as bioindicators of pollution: a review of Italian research over the last three decades. Rev De Micropaleontol 54:115-127. https://doi.org/10.1007/bf01611364

Gooday AJ, Jorissen F, Levin LA, Middelburg JJ, Naqvi SWA, Rabalais NN, Scranton M, Zhang J (2009) Historical records of coastal eutrophication-induced hypoxia. Biogeosciences 6(8):1707-1745. https://doi.org/10.5194/bg6-1707-2009

Hayward BW, Grenfell HR, Nicholson K, Parker R, Wilmhurst J, Horrocks M, Swales A, Sabaa AT (2004) Foraminiferal record of human impact on intertidal estuarine environments in New Zealand's largest city. Mar Micropaleontol 53(1-2):37-66. https://doi.org/10.1016/j.marmicro.2004. 03.001

Hazel J (1975) Patterns of marine ostracode diversity in the Cape Hatteras, North Carolina, area. J Paleontol 49:731-744

Herut B, Sandler A (2006) Normalization Methods for pollutants in marine sediments: review and recommendations for the mediterranean. Israel Oceanograp Limnol Res, Report H18(2006):1-23

Holbourn et al., 2013 A Holbourn AS Henderson N MacLeod 2013 Atlas of benthic foraminifera John Wiley \& Sons Natural History Museum London https://doi.org/10.1002/ 9781118452493

Y Hong 2016 Hong Kong shallow marine benthic ecosystem history: conservation paleoecology approach based on microfossil ostracods Thesis University of Hong Kong https://doi.org/10.5353/th_991022192279703414

Horowitz AJ (1985) A Primer on trace metal-sediment chemistry united states geological survey. Water-Supply Paper 2277(1):67. https://doi.org/10.3133/wsp2277 
Horowitz AJ (1991) A primer on sediment-trace element chemistry, 2nd Edition, United States Geological Survey, Open-File Report 91-76:1-136. https://doi.org/10.3133/ ofr9176

Hyams-Kaphzan O, Almogi-Labin A, Benjamini C, Herut B (2009) Natural oligotrophy vs pollution-induced eutrophy on the SE Mediterranean shallow shelf (Israel): environmental parameters and benthic foraminifera. Mar Pollut Bull 58(12):1888-1902. https://doi.org/10.1016/j. marpolbul.2009.07.010

Irizuki T, Ito H, Sako M, Yoshioka K, Kawano S, Nomura R, Tanaka Y (2015) Anthropogenic impacts on meiobenthic Ostracoda (Crustacea) in the moderately polluted Kasado Bay, Seto Inland Sea, Japan, over the past 70 years. Mar Pollut Bull 91(1):149-159. https://doi.org/10.1016/j. marpolbul.2014.12.013

Irizuki T, Hirose K, Ueda Y, Fujihara Y, Ishiga H, Seto K (2018) Ecological shifts due to anthropogenic activities in the coastal seas of the Seto Inland Sea, Japan, since the 20th century. Mar Pollut Bull 127:637-653. https://doi.org/10. 1016/j.marpolbul.2017.12.050

Isaia R, Vitale S, Marturano A, Aiello G, Barra D, Ciarcia S, Iannuzzi E, Tramparulo FDA (2019) High-resolution geological investigations to reconstruct the long-term ground movements in the last $15 \mathrm{kyr}$ at Campi Flegrei caldera (southern Italy). J Volcanol Geotherm Res 385:143-158. https://doi.org/10.1016/j.jvolgeores.2019. 07.012

Li T, Li X, Zhong H, Yang C, Sun G, Luo W (2015) Distribution of trace metals and the benthic foraminiferal assemblage as a characterization of the environment in the north Minjiang River Estuary (Fujian, China). Mar Pollut Bull 90(1-2):227-241. https://doi.org/10.1016/j.marpolbul. 2014.10.047

Mangoni O, Aiello G, Balbi S, Barra D, Bolinesi F, Donadio C, Ferrara L, Guida M, Parisi R, Pennetta M, Trifuoggi M, Arienzo M (2016) A multidisciplinary approach for the characterization of the coastal marine ecosystems of Monte di Procida (Campania, Italy). Mar Pollut Bull 112(1-2):443-451. https://doi.org/10.1016/j.marpolbul. 2016.07.008

Martins MVA, Zaaboub N, Aleya L, Frontalini F, Pereira E, Miranda P, Mane M, Laut Rocha F, L, El Bour M, (2015) Environmental quality assessment of Bizerte Lagoon (Tunisia) using living foraminifera assemblages and a multiproxy approach. PLoS One 10(9):e0137250. https:// doi.org/10.1371/journal.pone.013725

Marturano A, Aiello G, Barra D, Fedele L, Grifa C, Morra V, Berg R, Varone A (2009) Evidence for holocenic uplift at somma-vesuvius. J Volcanol Geotherm Res 184(3-4):451-461. https://doi.org/10.1016/j.jvolgeores. 2009.05.020

Marturano A, Aiello G, Barra D (2011a) Evidence for late pleistocene uplift at the somma-vesuvius apron near Pompeii. J Volcanol Geotherm Res 202(3-4):211-227. https://doi.org/10.1016/j.jvolgeores.2011.02.010

Marturano A, Aiello G, Barra D, Fedele L, Morra V (2011b) Ground movement at somma-vesuvius from last glacial maximum. J Volcanol Geotherm Res 211-212:24-35. https://doi.org/10.1016/j.jvolgeores.2011.10.003
Marturano A, Aiello G, Barra D (2013) Somma-Vesuvius ground deformation over the last glacial cycle. J Volcanol Geotherm Res 255:90-97. https://doi.org/10.1016/j. jvolgeores.2013.02.007

Marturano A, Isaia R, Aiello G, Barra D (2018) Complex dome growth at Campi Flegrei caldera (Italy) in the last $15 \mathrm{ka}$. J Geophys Res Solid Earth 123(9):8180-8197. https://doi. org/10.1029/2018JB015672

Mazzola A, Mirto S, Danovaro R (1999) Initial fish-farm impact on meiofaunal assemblages in coastal sediments of the Western Mediterranean. Mar Pollut Bull 38(12):1126-1133. https://doi.org/10.1016/S0025326X(99)00142-3

Menna M, Mercatini A, Uttieri M, Buonocore B, Zambianchi E (2008) Wintertime transport processes in the Gulf of Naples investigated by HF radar measurements of surface currents. Il Nuovo Cimento 30(6):605-622. https://doi.org/ 10.1393/ncc/i2008-10270-0

Moncharmont-Zei M (1964) Studio ecologico sui Foraminiferi del Golfo di Pozzuoli (Napoli). Pubblicazioni Della Stazione Zoologica Di Napoli 34:160-184

Morley MS, Hayward BW (2014) Biodiversity and distribution of Ostracoda, Foraminifera and Micromollusca of Matai Bay, Northland. Records of the Auckland Museum 49:55-80

Mostafawi N (2001) How severely was the Persian Gulf affected by oil spills following the 1991 Gulf War? Environ Geol 40(10):1185-1191. https://doi.org/10.1007/ s002540100238

Müller GW (1894) Die Ostracoden des Golfes von Neapel und der angrenzenden Meeres-Abschnitte Fauna Und Flora Des Golfes Von Neapel Und Der Angrenzenden Meeres-Abschnitte. Herausgegeben Von Der Zoologischen Station Zu Neapel 21(1):404

Pascual A, Rodríguez-Lázaro J, Martin-Rubio M, Jouanneau J-M, Weber O (2008) A survey of the benthic microfauna (foraminifera, Ostracoda) on the Basque shelf, southern Bay of Biscay. J Mar Syst 72:35-64. https://doi.org/10. 1016/j.jmarsys.2007.05.015

Pérès JM (1982) Major Benthic Assemblages. In: Kinne O (ed) Marine Ecology, A Comprehensive, Integrated Treatise on Life in Oceans and Coastal Waters. John Wiley \& Sons, Ltd., Chichester. 5: 373-522

Peres JM, Picard J (1964) Nouveau manuel de bionomie benthique de la Mer Méditerranée. Recueil Des Travaux De La Station Marine D'endoume, Marseille 31:1-137

Petrosino P, Angrisani AC, Barra D, Donadio C, Aiello G, Allocca V, Coda S, De Vita P, Jicha BR, Calcaterra D (2021) Multiproxy approach to urban geology of the historical center of Naples. Italy, Quat Intern 577:147-165. https://doi.org/10.1016/j.quaint.2020.12.043

Pokorný V (1978) Ostracodes. In: Haq BU, Boersma A. (eds) Introduction to marine micropaleontology. Elsevier, Amsterdam, pp 109-149. https://doi.org/10.1016/B978044482672-5/50004-0

Puri HS (1966) Ecologic Distribution of Recent Ostracoda. In: Proceedings of the Symposium on Crustacea, part 1. Marine Biological Association of India Symposium Series, pp 457-495 
Puri HS (1971) Distribution of ostracodes in the oceans. In: Riedel WR (ed) Funnell BM. The Micropalaeontology of Oceans, Cambridge University Press, pp 163-169

Puri HS, Bonaduce G, Malloy J (1964) Ecology of the Gulf of Naples. Pubblicazioni della Stazione Zoologica di Napoli 33 suppl.:88-199

Puri HS, Bonaduce G, Gervasio AM (1969) Distribution of Ostracoda in the Mediterranean. In: Neale JW (ed) The Taxonomy. Oliver \& Boyd, Morphology and Ecology of Recent Ostracoda, pp 358-411

Ministero dell'Ambiente e della Tutela del Territorio, (2003). Decreto 6 Novembre 2003, n. 367. Regolamento concernente la fissazione di standard di qualità nell'ambiente acquatico per le sostanze pericolose, ai sensi dell' articolo 3, comma 4, del decreto legislativo 11 maggio 1999, n. 152. Gazzetta Ufficiale della Repubblica Italiana n. 5 dell'8 gennaio 2004

Ministero dell'Ambiente e della Tutela del Territorio e del Mare, (2009) Decreto 14 aprile 2009 n. 56. Regolamento recante Criteri tecnici per il monitoraggio dei corpi idrici e l'identificazione delle condizioni di riferimento per la modifica delle norme tecniche del decreto legislativo 3 aprile 2006, n. 152, recante Norme in materia ambientale, predisposto ai sensi dell' articolo 75, comma 3, del decreto legislativo medesimo. Gazzetta Ufficiale della Repubblica Italiana n. 124 del 30 maggio 2009

Romano E, Bergamin L, Ausili A, Pierfranceschi G, Maggi C, Sesta G, Gabellini M (2009) The impact of the Bagnoli industrial site (Naples, Italy) on sea-bottom environment. Chemical and textural features of sediments and the related response of benthic foraminifera. In: Romano E, Bergamin L (eds) Foraminifera and marine pollution. Mar Pollut Bull 59:245-256. https://doi.org/10.1039/c3em30824c

Romano E, Bergamin L, Celia Magno M, Ausili A (2013) Sediment characterization of the highly impacted Augusta harbour (Sicily, Italy): modern benthic foraminifera in relation to grain-size and sediment geochemistry. Environ Sci Process Impacts 15:930-946. https://doi.org/10.1039/ c3em30824c

Ruiz F, González-Regalado ML, Galán E, González MI, Prudencio MI, Dias MI, Abad M, Toscano A, Prenda J, García EXM (2012) Benthic foraminifera as bioindicators of anthropogenic impacts in two north African lagoons: a comparison with ostracod assemblages. Rev Mex De Cienc Geol 29:527-533

Salvi G, Buosi C, Arbulla D, Cherchi A, De Giudici G, Ibba A, De Muro S (2015) Ostracoda and foraminifera response to a contaminated environment: the case of the Ex-Military Arsenal of the La Maddalena Harbour (Sardinia, Italy). Micropaleontology 61:115-133

Samir AM (2000) The response of benthic foraminifera and ostracods to various pollution sources: a study from two lagoons in Egypt. J Foraminiferal Res 30(2):83-98. https:// doi.org/10.2113/0300083

Samir AM, El-Din AB (2001) Benthic foraminiferal assemblages and morphological abnormalities as pollution proxies in two Egyptian bays. Mar Micropaleontol 41(3-4):193-227. https://doi.org/10.1016/S03778398(00)00061-X

Schornikov EI (2000) Ostracoda as indicators of conditions and dynamics of water ecosystems. In: Martin RE. (ed)
Environmental Micropaleontology, Topics in Geobiology, Kluwer Academic/Plenum Publishers, New York 15:181-187. https://doi.org/10.1007/978-1-4615-4167-7_ 9

Sgarrella F, Barra D (1985) Distribuzione dei Foraminiferi bentonici nel Golfo di Salerno (Basso Tirreno, Italia). Bollettino Della Società Dei Naturalisti in Napoli 93:1-58

Sgarrella F, Moncharmont Zei M (1993) Benthic Foraminifera of the Gulf of Naples (Italy): systematics and autoecology. Boll Soc Paleontol Ital 32:145-264

Sgarrella F, Barra D, Improta A (1985) The benthic foraminifers of the Gulf of Policastro (Southern Tyrrhenian Sea, Italy). Bollettino Della Società Dei Naturalisti in Napoli 92:67-114

Sharp WE, Nardi G (1987) A study of the heavy-metal pollution in the bottom sediments at Porto Di Bagnoli (Naples). Italy. J Geochem Explor 29(31-48):31-48. https://doi.org/10. 1016/0375-6742(87)90069-0

Somma R, Iuliano S, Matano F, Molisso F, Passaro S, Sacchi M, Troise C, De Natale G (2016) High-resolution morphobathymetry of Pozzuoli Bay, southern Italy. J Maps 12(2):222-230. https://doi.org/10.1080/17445647.2014. 1001800

Tammaro U, Obrizzo F, Riccardi U, La Rocca A, Pinto S, Brandi G, Vertechi E, Capuano P (2021) Neapolitan volcanic area Tide Gauge Network (southern Italy): ground displacements and sea-level oscillations. Adv Geosci 52:108-118. https://doi.org/10.5194/adgeo-52-105-2021

Temelkov BK (2008) Ecological Characteristics of the Foraminiferal Fauna (Protozoa: Foraminifera) of the Bulgarian South Black Sea area. Acta Zool Bulg 2:275-282

Triantaphyllou MV, Tsoyroy T, Dermitzakis MD, Koykoysioyra O (2003) Epiphythal ostracode and benthic foraminiferal assemblages: investigating their role as environmental health proxies in the marine ecosystems of SE Andros Island (Middle Aegean Sea, Greece). 8th International Conference on Environmental Science and Technology, Lemnos island, Greece, 8-10 September 2003: 879-887

Trifuoggi M, Donadio C, Mangoni O, Ferrara L, Bolinesi F, Nastro RA, Stanislao C, Toscanesi M, Di Natale G, Arienzo M (2017) Distribution and enrichment of trace metals in surface marine sediments in the Gulf of Pozzuoli and off the coast of the brownfield metallurgical site of Ilva of Bagnoli (Campania, Italy). Mar Pollut Bull 124:502-511. https://doi.org/10.1016/j.marpolbul.2017. 07.033

Trifuoggi M, Donadio C, Ferrara L, Stanislao C, Toscanesi M, Arienzo M (2018) Levels of pollution of rare earth elements in the surface sediments from the Gulf of Pozzuoli (Campania, Italy). Mar Pollut Bull 136:374-384. https:// doi.org/10.1016/j.marpolbul.2018.09.034

Vilela CG, Sanjinés AES, JrRO G, Mendonça Filho JG, Baptista Neto JA, Barbosa CF (2003) Search for Bioindicators of Pollution in the Guanabara Bay: Integrations of Ecologic Patterns. Anu Do Inst De Geocienc - UFRJ 26:25-35

Wilkinson IP, Poirier C, Head MJ, Sayer CD, Tibby J (2014) Microbiotic signatures of the Anthropocene in marginal marine and freshwater palaeoenvironments. In: Zalasiewicz JA, Williams M, Ellis MA, Snelling AM (eds) Waters 
CN. A stratigraphical basis for the Anthropocene, London . https://doi.org/10.1144/sp395.14

Yasuhara M, Hunt G, Breitburg D, Tsujimoto A, Katsuki K

(2012) Human-induced marine ecological degradation: micropaleontological perspectives. Ecol Evol 2(12):3242-3268. https://doi.org/10.1002/ece3.425
Publisher's Note Springer Nature remains neutral with regard to jurisdictional claims in published maps and institutional affiliations. 